Review Article

\title{
Effect of P Application Rate and Rhizobium Inoculation on Nodulation, Growth, and Yield Performance of Chickpea (Cicer arietinum L.)
}

\author{
Mebrahtu Gebremariam (iD ${ }^{1}$ and Teklay Tesfay ${ }^{2}{ }^{2}$ \\ ${ }^{1}$ Department of Plant Sciences (Horticulture Program), Aksum University Shire Campus, P.O. Box 314, Shire, Ethiopia \\ ${ }^{2}$ Department of Plant Sciences, Aksum University Shire Campus, P.O. Box 314, Shire, Ethiopia \\ Correspondence should be addressed to Mebrahtu Gebremariam; mebre2003hu@gmail.com
}

Received 25 September 2020; Accepted 31 May 2021; Published 12 June 2021

Academic Editor: Allen Barker

Copyright (c) 2021 Mebrahtu Gebremariam and Teklay Tesfay. This is an open access article distributed under the Creative Commons Attribution License, which permits unrestricted use, distribution, and reproduction in any medium, provided the original work is properly cited.

\begin{abstract}
Chickpea (Cicer arietinum L.) is the world's third most vital food legume after beans and peas in production level. Yet, its productivity in the last decade has been declined, and it has been contended that the usual native soil rhizobial populations are insufficient/ineffective in $\mathrm{N}_{2}$-fixation. Rhizobium inoculation of the seed may substitute costly $\mathrm{N}$-fertilizers and provide a useful way of achieving sustainable production. Hence, to supply an adequate rhizobial population in the rhizosphere, seed inoculation of chickpea with an effective and importunate rhizobial strain is essential in soils having no/feeble bacterial existence and has revealed optimistic effect on nodule number and mass, growth, yield, and its attributes over uninoculated ones. Its effect has been influenced by $\mathrm{N}$ content and P-deficiency of soil, rhizobium strain, variety, $\mathrm{T}^{\circ}, \mathrm{pH}$, salinity, and moisture stress. Phosphorus (P) demand is high in chickpeas, and P deficiency also has a negative effect on chickpea production success. Several research results revealed significant effects of $\mathrm{P}$ rate $\left(30-200 \mathrm{~kg} \mathrm{P}_{2} \mathrm{O}_{5} \mathrm{ha}^{-1}\right)$ on nodule number, mass, and rating plant $^{-1}$; LAI, RGR, DM, plant height, and branches plant ${ }^{-1}$; pods and grains plant ${ }^{-1}$, grain and biomass yields, 100-grain weight, and $\mathrm{HI}$ compared to the control. $\mathrm{P}$ rates response has been affected by moisture level, $\mathrm{pH}$, available $\mathrm{P}$ and $\mathrm{N}$, and variety. Particularly, joint use of $\mathrm{P}$ rate and rhizobium inoculation on chickpea has been stated to improve nodulation, growth, and yield and soil fertility. Various studies on the integrated use of $\mathrm{P}$ rate and rhizobium inoculation under varying situations showed enhanced nodulation, growth, and yield over the $\mathrm{P}$ rate or rhizobium inoculation alone. This might be attributed to adequate $\mathrm{P}$ supply and improved utilization with the provision of suitable N2-fixing bacteria for enhanced nodulation and adequate $\mathrm{N}$ supply.
\end{abstract}

\section{Introduction}

Chickpea (Cicer arietinum L.) is one of the cool season crops and has most likely been originated in the area of presentday southeastern Turkey and adjacent Syria [1]. The cultivated chickpea is among the first grain legumes that have been domesticated in the Old World [2]. It has been one of the most important legume crops in the Mediterranean Basin and Turkey for human nutrition for centuries [3]. Nowadays, chickpea is widely being produced by smallholders in Mediterranean and semiarid climates, but in Africa, it is mainly limited to the cool highlands of Ethiopia
[4]. Its ability to acquire maturity in 3-6 months under diverse agroecological conditions is demonstrated to have the wider adaptability to various climates [5]. Chickpea is moderately drought tolerant, partially because it may extract water from deep layers of soil profiles through its proliferating rooting habits, and is well adapted to other environmental stresses such as high temperatures and soils of low fertility [6].

Chickpea is the world's third most significant food legume after beans and peas on the basis of production level. The top five chickpea producing countries in the world during 2017 were India $(9,075,000 \mathrm{t})$, Australia $(2,004,000 \mathrm{t})$, 
Myanmar (526,772t), Ethiopia $(473,570 \mathrm{t})$, and Turkey $(470,000 \mathrm{t})$ [7]. It has numerous roles in traditional farming system. It is a significant source of human food and animal feed, and it is a source of cash income for farmers in developing countries [8]. Chickpea seeds contain $20.6 \%$ protein, $61.2 \%$ carbohydrate, and $2.2 \%$ fat $[9,10]$, and hence, it is a good source of relatively cheap energy, protein, and potentially health-beneficial phytochemicals [11]. Additionally, it provides oil, significant quantities of vitamins (A, B, and $\mathrm{C})$, and minerals ( $\mathrm{Fe}, \mathrm{P}$, and $\mathrm{Ca}$ ) for human nutrition [12]. The crop further plays a vital function in the sustaining of soil fertility $[13,14]$, primarily in dry and rain-fed areas through $\mathrm{N}_{2}$-fixation, and, as a rotation crop, allowing the diversification of agricultural production systems $[6,15]$, and solubilisation of unavailable soil phosphorus [16] that may be useful to other crops in the system. Moreover, chickpea has been widely used as green manure.

The average global productivity of chickpea is $1.80 \mathrm{t} \mathrm{ha}^{-1}$, whereas it is $1.46 \mathrm{tha}^{-1}$ in West and South Asia. In other developing countries like Turkey, Myanmar, Ethiopia, and Mexico, the yield level surpasses $1.80 \mathrm{tha}^{-1}$. The yield reports are above $2.00 \mathrm{tha}^{-1}$ in Yemen and Russia. Besides, similar or relatively higher yields have been found in most developed countries [17]. The productivity is, thus, far below the potential yield of $4.5 \mathrm{tha}^{-1}$ [18]. This yield gap of chickpea is due to inappropriate water use, $\mathrm{N}_{2}$, and P deficiencies [19]. Proper application of plant nutrition is one of the crucial management factors used to achieve higher productivity of crops [20]. P is the second most essential macronutrient needed for grain legumes like chickpea, next to $\mathrm{N}_{2}$ [21], and it has significant effects on growth and yield performance [22]. It is required for efficient and early root development [23], $\mathrm{N}_{2}$-fixation (enhanced nodulation) [24, 25], increased leaf size and branching [26], photosynthesis process [27], constituents of ATP and ADP [28], flowering, seed formation [28], grain yield [29], increased resistance to plant diseases [30], and hastening crop maturity [22]. However, P has most frequently been identified as a deficient nutrient in most soils especially in the tropics [31, 32], and it makes the situation most serious since the $\mathrm{P}$ necessity of legumes is greater as compared to cereals [33]. Hence, the use of an optimum rate of $\mathrm{P}$ fertilizer and improved $\mathrm{P}$ use efficiency have a major effect on enhancing the growth and productivity of legume crops such as chickpea [34]. The effect of $P$ fertilizer rates on the growth and yield of chickpea has sufficiently been documented in various chickpea producing areas [35-38].

Mineral fertilizers are applied to the soil to supplement or replace biological functions, which are regarded as insufficient or inefficient for attaining the desired levels of production $[39,40]$. Currently, above $48 \%$ of more than 7 billion peoples of the world are living because of boosted crop production made possible by using nitrogenous fertilizer (N-fertilizer) [41]. Nevertheless, with fertilizers being chemicals, they may definitely disturb the normal functioning of soil and could further affect the output of other ecological services $[40,42]$. Besides, the use of high rate $\mathrm{N}$-fertilizer is among the factors causing an adverse situation of water pollution and eutrophication of lakes, as well as rivers [43]. $\mathrm{N}_{2}$-fixation by legumes (BNF) is an appropriate alternative and has become the second most important biochemical process on Earth next to photosynthesis [44] and provides $\mathrm{N}$ to achieve the $\mathrm{N}$ needs of both legumes and the subsequent crops [45]. It is the biochemical process in which rhizobia bacterial symbionts of legumes fix atmospheric $\mathrm{N}_{2}$ into plant available form via nitrogenase enzyme activity [46]. BNF is cost-effective, eco-friendly, and renewable source of plant nutrition [47]. $\mathrm{N}_{2}$-fixation helps reduce the necessity for mineral fertilizers and diminish its hostile consequences on the environment [48]. In improving sustainable agricultural practices, $\mathrm{N}_{2}$-fixation by legumes has an immense effect in lessening environmental pollution and worsening of nature [49-51]. Amongst all the $\mathrm{N}_{2}$-fixing microorganisms, the symbiotic association between legumes and rhizobia is responsible for the largest contribution of fixed $\mathrm{N}$ to farming systems [52]. When effectively nodulated, legumes can fix about $60-80 \%$ of their $\mathrm{N}$ requirements [53]. Different legumes can obtain varying amounts of $\mathrm{N}$ via symbiotic association with bacteria [54], for example, faba bean and soybean fix about comparable quantities of $\mathrm{N}$ up to (200) followed by cow pea (125), peas and lentils (85), chickpea and common bean (50), and groundnut (48) $\mathrm{kg} \mathrm{Nha}^{-1}$ [55-58]. The efficiency of legumes to fix $\mathrm{N}_{2}$ biologically is influenced by various factors including soil moisture, temperature, available soil nutrients, biotic and abiotic stresses, and the existence of efficient, competitive rhizobia strains, cropping systems, and field management practices [59-61].

Like other legumes, chickpea can obtain a significant fraction (4-85\%) of its $\mathrm{N}$ requirement through its highly specific symbiotic association with effective and compatible rhizobium strains [62], which is vital for the formation of nodules and $\mathrm{N}_{2}$-fixation. The rest of $\mathrm{N}$ is obtained from soil inorganic $\mathrm{N}$, mineralized organic matter, and residual $\mathrm{N}$ from the previous crop, and/or fertilizer applications $[63,64]$. Various research findings indicate a varying amounts of $\mathrm{N}$ fixed through the symbiotic association of chickpea and Rhizobium leguminosarum subsp. ciceri in a season, i.e., up to 140 [65], 176 [66], 100 [67], 25-30 [68], and $26-40 \mathrm{~kg} \mathrm{Nha}^{-1}$ [56]. The effectiveness of $\mathrm{N}_{2}$-fixation is influenced by cultural practices $[62,69]$ and environment [60] depending on factors such as soil $\mathrm{pH}$, soil moisture, organic matter, native strains, and soil temperature [70, 71]. However, it has been reported that chickpea has lower performance than other grain legumes in relation to $\mathrm{N}_{2}$ fixation [72], especially where native rhizobial populations are low or ineffective [73]. Therefore, inoculation of legumes in general and chickpea in particular with selected rhizobium bacteria strains is indispensable, while there is a lack of compatible rhizobium or where native rhizobial populations are low or incompetent for improved $\mathrm{N}_{2}$ fixation (and hence growth and yield) [74]. In this aspect, rhizobium inoculation of seed may replace costly $\mathrm{N}$ fertilizers, and it is typically a more efficient agronomic operation to ensure sufficient $\mathrm{N}$ nutrition of chickpea than the use of $\mathrm{N}$ fertilizer [68]. Different research works have confirmed the effects of rhizobium inoculation of seeds on nodulation, growth, yield, and its attributes of chickpea $[62,69]$. Conversely, the 
process of $\mathrm{N}_{2}$-fixation is largely sensitive to the deficiency of $\mathrm{P}$, via its influence on the growth and survival of rhizobia, nodule formation, nodule functioning, and growth of the host plants $[22,75]$. Although there are various studies in relation to the effects of separate/integrated use of $\mathrm{P}$ rate and rhizobium inoculation on nodulation, growth, and yield of chickpea $[32,76]$, there has not been a review about such research findings; hence, considering its significance, the aim of this paper is to review the effect of $\mathrm{P}$ rates and rhizobium inoculation on nodulation, growth, and yield of chickpea.

\section{Effect of Rhizobium Inoculation on Nodulation, Growth, and Yield Performance of Chickpea}

Some microorganisms are capable of forming a close relationship with plants that can be either harmful or valuable to the plants. Rhizobia are the sole type of bacterial symbionts of legumes that fix free atmospheric $\mathrm{N}_{2}$ [77]. Of the $\mathrm{N}_{2}$-fixing bacteria, symbiotic associations of legumes and rhizobia accounted for the largest provision of fixed $\mathrm{N}$ in farming systems [52]. Additionally, it has been studied that rhizobial strains improve plant growth via other means like phosphate solubilisation ability in some legumes [16] and reduction of plant ethylene quantities using ACC deaminase activity [78]. Nevertheless, among the legumes, chickpea production during the last decade has been declined, and it has been contended that the usual indigenous soil rhizobial populations are insufficient and ineffective in biological $\mathrm{N}_{2}$ fixation [73]. Hence, to make sure of an adequate rhizobial population in the rhizosphere, seed inoculation with an effective and importunate rhizobial strain for legumes like chickpea is essential in soils having no or feeble bacterial existence [79]. This helps in improving nodulation, $\mathrm{N}_{2}$-fixation, growth, and yield [80]. In this regard, rhizobium inoculation of chickpea seeds may substitute costly $\mathrm{N}$-fertilizers and has been stated to be useful [81]. Depending on the availability of a suitable amount, the mineral $\mathrm{N}$ content of a given soil can have both beneficial and detrimental consequences on the growth and yield response of chickpeas for inoculation . Usually, a higher mineral $\mathrm{N}$ content in the rhizosphere results in poor $\mathrm{N}_{2}$-fixation with inhibition of nodulation of chickpea [82], possibly by reducing the nitrogenase activity [83] and/or lessening the flavonoids and isoflavonoids in roots of the plant toward the soils [84]. Brockwell et al. [85] confirmed that nodulation has been decreased at high $\mathrm{N}$ rates irrespective of levels of inoculation. Similar findings have been signified in chickpea [86] and beans [87]. Furthermore, various study results revealed the reduction in nodule formation (nodule number and dry weight) with increased application rates of inorganic $\mathrm{N}$ to inoculated chickpea $[82,83]$. Conversely, small amounts of $\mathrm{N}$ in soil or fertilizers frequently have a stimulatory result on nodulation and $\mathrm{N}_{2}$ fixation that is chiefly due to the positive effect of $\mathrm{N}$ on plant establishment and growth during root emergence and the onset of active $\mathrm{N}_{2}$-fixation [88]. Thus, it has been indicated that low rates of $\mathrm{N}$ fertilizer coupled with inoculation with chosen rhizobial strains can stimulate $\mathrm{N}_{2}$ fixation, plant growth, and grain yield [83].

Globally, many research findings revealed the optimistic effect of rhizobium inoculation on nodulation, growth, and yield performance in chickpea $[48,89,90]$ that could be ascribed to boosted root surface and enhanced nutrient acquirement [91], enhanced growth and development of the organs of photosynthesis and the level of assimilates accretion [92], along with the synthesizing of diverse phytohormones like indole acetic acid (IAA) [93]. Aslam et al. [94] reported that chickpea inoculation with rhizobium strains had a pronounced effect on nodule mass, as well as root fresh weight compared to uninoculated treatment. The highest $(0.40 \mathrm{~g})$ and lowest $(0.10 \mathrm{~g})$ nodule mass plant ${ }^{-1}$ were obtained from a mixture of Thal-8 and TAL-620 and uninoculated treatments, respectively. Moreover, the highest $(88.57 \mathrm{~g})$ and lowest $(56.31 \mathrm{~g})$ root fresh weight plant ${ }^{-1}$ were recorded in a mixture of Thal- 8 and TAL620 and the uninoculated treatments, consecutively. Moreover, a research finding by Khaitov et al. [14] signified that inoculation of chickpea plants with strains of rhizobium sp. R4, R6, and R9 significantly increased shoot dry matter, root dry matter, and nodule number by 17,12 , and $20 \%$ above the uninoculated plants, serially. Shoot length, root length, shoot dry weight, and root dry weight of inoculated plants increased by $52,43,36$, and $64 \%$, in that order, compared to the uninoculated plants. Inoculation significantly increased pod number (28\%) and yield (55\%) over uninoculated plants. The growth potential of chickpea has been revealed to be relying upon the rhizobia relationship and plant genotype that jointly persuades the symbiotic ability [95]. A two-year study result indicated that grain yield and its attributes of chickpea were significantly affected by rhizobium inoculation in both years except harvest index and biological yield of the first year. Inoculation increased plant height (3.32\%), first pod height (7.25\%), branches plant ${ }^{-1}(4.08 \%)$, pods plant ${ }^{-1}(6.90 \%)$, grains plant $^{-1}(6.40)$, and grain yield (6.30\%) over the control [10]. It has been reported that increased nodulation due to rhizobium inoculation resulted in higher $\mathrm{N}_{2}$-fixation and ultimately resulted in higher pod number plant ${ }^{-1}$, which offered higher grain yields as a whole [8].

In the study conducted by Gul et al. [96], chickpea germplasms were typed for nodulation and evaluated against seed inoculation with rhizobium for number of nodules and grain yield plant ${ }^{-1}$, and as a result, was observed 43 genotypes showed nodulation and 4 genotypes failed to produce nodules. The inoculated genotypes significantly exceeded the control in terms of nodule number (10.86 and 7.86) and grain yield (15.10 and $10.00 \mathrm{~g})$ plant $^{-1}$, respectively. Similarly, Ogola [97] reported that the number and dry weight of nodules plant ${ }^{-1}$ were greater with inoculation compared to the control. Amongst the inoculated treatments, genotype ICCV-5103 produced greater number and dry weight of nodules plant ${ }^{-1}$ ( 3 and $0.0045 \mathrm{~g}$ ), over genotype ICCV-7116 ( 2 and $0.0025 \mathrm{~g}$ ). Nodules plant ${ }^{-1}$ indicated in such study was greatly lower than previous research findings $[48,69]$, and it has been suggested that the lower nodule number might be ascribed partially to low soil $\mathrm{pH}[70]$ and moisture 
stress [98]. It has been disclosed that the growth and yield potential of chickpea depend upon the rhizobia association and plant genotype, which jointly affect the symbiotic success $[95,99]$. Nishita and Joshi $[100]$ executed a pot trial to look at the growth and yield response of chickpea to rhizobium inoculation and showed that inoculated plants gave significantly higher nodule number and weight, root length and weight, shoot length and weight, seed, and biological yields compared to uninoculated plants. Furthermore, Meleta and Abera [32] observed that all the nodulation parameters, except nodule color, were significantly affected by rhizobium inoculation. Inoculation with EAL 029 significantly increased nodulation rate (10.81\%), nodule dry weight $(4.94 \%)$, and nodules plant ${ }^{-1}(7.19 \%)$ against uninoculated plants. This substantial rise in nodulation attributes of inoculated plants might be because of the inoculated bacteria strains that had good nodulation inducing capacity over the native soil rhizobium population [101]. In other research findings, it has been specified that the higher nodulation due to inoculation resulted in higher $\mathrm{N}_{2}$-fixation and eventually produced higher pods plant ${ }^{-1}$, which resulted in higher grain yield [102]. There have been various research reports demonstrating the positive effect of inoculation on nodulation, growth, and yield contrary to uninoculated plants in chickpea $[48,90]$. However, nonsignificant variations were observed between rhizobium inoculated and control for plant height, crop biomass, and grain yield and harvest index [97].

A study indicated that rhizobium inoculation had a significant effect on grain yield, and maximum $\left(1.44 \mathrm{tha}^{-1}\right)$ and minimum $\left(1.15 \mathrm{tha}^{-1}\right)$ yields were obtained from the rhizobium inoculated and uninoculation treatments, serially (i.e., there was an increase of $0.29 \mathrm{tha}^{-1}$ when seed pelleted with rhizobium) [86].However, other trials on inoculation of chickpea varieties disclosed that inoculated plants had significantly higher nodule number $(26.70 \%)$ and weight (27.07\%), stover (16.94\%), and grain $(15.50 \%)$ yield over uninoculated plants. Variety of BARI Chola-3 produced the highest nodule number $(42.60)$ and weight $(0.29 \mathrm{~g})$, and stover yield $\left(2.42 \mathrm{tha}^{-1}\right)$, while the highest grain yield was obtained from BARI Chola- $4\left(1.35 \mathrm{tha}^{-1}\right)$. The disparity of varieties for such attributes may result from the variation in genetic makeup and inherited characters among varieties [103]. A similar study showed a significant increase in nodulation $(17.50 \%)$, plant height $(4.00 \%)$, pods plant ${ }^{-1}$ (9.33\%), and grain yield $(7.50 \%)$ due to bacterial inoculation. The advanced line D-06052 had the highest grain yield $\left(2.89 \mathrm{tha}^{-1}\right)$ due to bacterial inoculation over the other advanced lines and the local cultivar. It was concluded that bacterial inoculation positively influenced the grain yield and its attributes and has been recommended for better chickpea yield [90]. Furthermore, significant disparity was found in nodule dry weight depending upon inoculants and cultivars [104]. A research result indicated that the seeds treated with rhizobium produced maximum nodules plant ${ }^{-1}(75.00)$, grains pod $^{-1}$ (3.00), pods plant ${ }^{-1}(49.00), 100$-grains weight $(24.74 \mathrm{~g})$, and biological $\left(5.17 \mathrm{tha}^{-1}\right)$ and grain $\left(1.44 \mathrm{tha}^{-1}\right)$ yields compared to uninoculated seeds [48].

A study performed in 2008 showed that rhizobium inoculation significantly increased nodules plant ${ }^{-1}$
(1075.49\%), nodules weight plant $^{-1}(1217.04 \%)$, primary branches plant $^{-1}(8.50 \%)$, secondary branches plant ${ }^{-1}$ (14.70\%), total pods plant ${ }^{-1}(8.00 \%)$, filled pods $(6.94 \%)$, unfilled pods $(6.08 \%)$, grains plant ${ }^{-1}(27.87 \%)$, and grain (7.01\%) and biological (7.28\%) yields over uninoculated plants [105]. It has been reported that bacterial inoculation increased the nodulation, and thus, yield increased due to the improved availability of $\mathrm{N}[90,106]$. An analogous finding indicated that rhizobium inoculation enhanced grain yield and its components except 100-grain weight under both normal irrigation and water-stressed conditions, but its performance was better under normal irrigation than water stress [107]. It has been suggested that it may be attributed to the fact that water stress has a decreasing effect on $\mathrm{N}_{2}$ fixation, growth, and yield $[98,108]$. It is sufficiently reported that, in chickpea under drought stress, yield reduction is a result of the adverse effect of water deficit on nodule function and symbiotic $\mathrm{N}_{2}$-fixation. On the contrary, the precise means accounting for the drought-provoked inhibition of symbiotic $\mathrm{N}_{2}$-fixation has continued to be mostly unrevealed [109]. Yet, in water-stress situation, it has also been confirmed that inoculation achieved superior performance than control [110]. Moreover, various studies have revealed that salinity and drought stress led to a significant decrease in plant biomass accumulation (root and shoots), nodule development, and nitrogenase activity, as well as strongly reduced yield of chickpea $[111,112]$. It has been found that there was a detrimental result of low (4.5) plus high (8.0) soil pH and temperature on rhizobial population in the soil [113]. It has been divulged that the salt tolerance capabilities of rhizobia could have a significant result on the thriving rhizobium-legume relationships in stress stipulations [15]. Symbiotic $\mathrm{N}_{2}$-fixation is dominated by a nitrogenase multifaceted that brings about the ATPreliant reduction of $\mathrm{N}_{2}$ to ammonium [114]. This enzyme complex has been anticipated as the chief intention being pretentious by a range of stresses, such as drought $[115,116]$, salinity [117], and P-deficiency [118]; such stresses may cause lessening in symbiotic $\mathrm{N}_{2}$-fixation and eventually a decrease in the yield performance of legume crops.

\section{Effect of P Application Rate on Nodulation, Growth, and Yield Performance of Chickpea}

Phosphorus (P) is a primary nutrient essential for plant growth and development, regulation of different enzymatic activities, and a constituent for energy transformation [119], whereas $\mathrm{P}$ deficient soil and low availability inflict major limitations on the vegetative, as well as reproductive growth and development of crops [120]. In legumes, in particular, there is a strong association between the $\mathrm{P}$ rate and the symbiotic mechanism and growth [121]. $\mathrm{N}_{2}$-fixation, nodulation, and specific nodule activity are closely associated with the P level and its availability in the soil [122]. Conversely, like in other crops, deficiency of $\mathrm{P}$ in soil (particularly in tropical soils) has an adverse impact on legumes in general, and chickpea production in special, as it is needed for energy transformation in nodules and improved $\mathrm{N}_{2}$ fixation, growth, yield, and quality $[25,38]$, and it causes 
substantial economic losses [123]. P restriction directly reduces photosynthesis by means of its negative effects on vegetative crop growth of leaf area development, and photosynthetic capability unit ${ }^{-1}$ leaf area [124]. The demand for $\mathrm{P}$ in chickpea is relatively in large amount for growth and has been revealed to improve leaf area, biomass, yield, number and mass of nodule [125]. Several studies have signified the important role of $\mathrm{P}$ in the growth and production of chickpea $[22,48,126]$.

As for the $\mathrm{P}$ application rates, $45 \mathrm{~kg} \mathrm{P}_{2} \mathrm{O}_{5} \mathrm{ha}^{-1}$ in chickpeas produced $24.2 \%$ more nodules plant ${ }^{-1}$ than the control, but it was found to be statistically on par with $30 \mathrm{~kg}$ $\mathrm{P}_{2} \mathrm{O}_{5}$ ha $^{-1}$ [127]. In an experiment, it was observed that all nodulation parameters excluding the nodule color of chickpea were significantly affected by $\mathrm{P}$ rate, and the maximum values were recorded at 45 and $60 \mathrm{~kg} \mathrm{P}_{2} \mathrm{O}_{5} \mathrm{ha}^{-1}$. Nodule rating and dry weight plant ${ }^{-1}$ increased at $60(47.50$ and $6.44 \%)$ and $45\left(52.30\right.$ and 6.60\%) $\mathrm{kg} \mathrm{P}_{2} \mathrm{O}_{5} \mathrm{ha}^{-1}$, respectively, relative to the control treatment [32]. In a trial comprising five rates of $\mathrm{P}$, Idris et al. [128] indicated that an increased $\mathrm{P}$ application level considerably enhanced both the number and dry weight of nodules in chickpea. The other research results indicated that the application of $46 \mathrm{~kg} \mathrm{Pha}^{-1}$ increased nodule number and dry weight plant ${ }^{-1}$ of chickpea by 157 and $114 \%$ over the control treatment, respectively [129]. In chickpea, adequate $P$ supply is essential for establishing successful symbiosis with $\mathrm{N}_{2}$-fixing rhizobacteria, and it excites nodulation, early root development, plant growth, and grain yield $[38,122]$. On the contrary, it has been disclosed that though $\mathrm{P}$ application rates improved dry matter and grain yields of lentil in a single responsive location in Saskatchewan, $\mathrm{N}_{2}$-fixation was not influenced [130]. The authors figured out that lentil was more affectable by $\mathrm{P}$ application than rhizobia, even though others have indicated that legume response to $\mathrm{P}$ can be ascribed to greater $\mathrm{N}_{2}$-fixing activity [131]. It has been revealed that $\mathrm{P}_{2} \mathrm{O}_{5}$ level of $60 \mathrm{~kg} \mathrm{ha}^{-1}$ showed a positive effect on the relative growth rate (RGR), dry matter accumulation (DM), nodulation, yield, and harvest index (HI) of chickpea [132]. A trial on bean plants showed a significant disparity among $\mathrm{P}$ application rates $\left(0,10,20\right.$, and $\left.30 \mathrm{~kg} \mathrm{Pha}^{-1}\right)$ for nodulation, growth, and yield attributes, where $20 \mathrm{~kg} \mathrm{Pha}^{-1}$ resulted in a 36 and $143 \%$ increase in plant growth and grain yield, respectively, compared to $0 \mathrm{~kg} \mathrm{Pha}^{-1}$ [133]. It has been disclosed in numerous research findings that an adequate rate of $\mathrm{P}$ is crucial for chickpea, as it is desired for energy transformation in nodules and improved $\mathrm{N}_{2}$-fixation, improved growth, yield, and quality $[25,36,38,48]$. However, it is frequently a major limiting nutrient in most of the tropical soils. Hence, the application of an optimum dose of $\mathrm{P}$ fertilizer and improved $\mathrm{P}$ use efficiency has a significant effect on improving the growth and productivity of legume crops like chickpea [22, 34].

A field trial signified that $\mathrm{P}$ levels significantly affected plant height, branches, and pods plant ${ }^{-1}$, and highest plant height $(39.25 \mathrm{~cm})$, branches plant ${ }^{-1}(9.37)$, and pods plant ${ }^{-1}$ (49.00) were recorded in $60 \mathrm{~kg} \mathrm{P}_{2} \mathrm{O}_{5} \mathrm{ha}^{-1}$, whereas the lowest plant height $(32.50 \mathrm{~cm})$, branches plant ${ }^{-1}(6.75)$, and pods plant $^{-1}$ (30.75) were obtained from the control [134].
Moinuddin et al. [92] indicated that $\mathrm{P}$ application rates had a significant effect on the growth attributes of chickpea, where progressive use of $\mathrm{P}$ enhanced the plant fresh and dry weight gradually, with $\mathrm{P}$ at $60 \mathrm{~kg} \mathrm{ha}^{-1}$ provided the best. For the rest of the growth attributes, $\mathrm{P}$ at 30 and $60 \mathrm{~kg} \mathrm{ha}^{-1}$ had statistically equal values. However, $\mathrm{P}$ of 30 and $60 \mathrm{~kg} \mathrm{ha}^{-1}$ proved invariably better than $\mathrm{P}$ at $0 \mathrm{~kg} \mathrm{ha}^{-1}$ for all growth parameters. A study revealed that yield attributes of chickpea cv. Anuradha were significantly influenced by $\mathrm{P}$ rate. $\mathrm{P}$ application of $60 \mathrm{~kg} \mathrm{ha}^{-1}$ resulted in significantly higher grain yield $\left(2.74 \mathrm{tha}^{-1}\right)$ mainly due to the significantly higher primary branches plant ${ }^{-1}(8.10)$, pods plant ${ }^{-1}$ (33.60), and 100 -grain weight $(13.10 \mathrm{~g})$. It improved the grain yield by $6.80 \%$ over $\mathrm{P}$ at $30 \mathrm{~kg} \mathrm{ha}^{-1}$ and $53.90 \%$ over the control [135]. Adequate P supply hastens root growth, cell division, and the progress of new tissues [22], and hence growth and yield $[25,38,48]$; possibly there has been an improved partitioning of biomass to the formation of pods and grain yield, owing to the enhanced development of the number of primary branches with the application of P fertilizer [136]. There have also been various research findings, which indicated significantly increased grain yield and its attributes of chickpea with an increase in $\mathrm{P}$ doses up to $60 \mathrm{~kg} \mathrm{ha}^{-1}$ $[36,48,137]$. It has been disclosed that $\mathrm{P}$ improved the photosynthetic efficiency and increased branches and pods plant $^{-1}$, thus giving rise to increased yield of plants [138].

On the contrary, the trial signified that total biomass and grain yields of chickpea were significantly influenced by $\mathrm{P}$ levels, and the average maximum total biomass $\left(4.05 \mathrm{tha}^{-1}\right)$ and grain $\left(2.11 \mathrm{tha}^{-1}\right)$ yields were observed at $90 \mathrm{~kg} \mathrm{P}_{2} \mathrm{O}_{5}$ $\mathrm{ha}^{-1}$, whereas the average lowest total biomass $\left(2.54 \mathrm{tha}^{-1}\right)$ and grain $\left(1.34 \mathrm{t} \mathrm{ha}^{-1}\right)$ yields were recorded in the control [94]. It could result from a plenty supply of $\mathrm{P}$ that, in turn, improved the carboxylation efficiency and boosted the ribulose1-5-diphosphate carboxylase activity, contributing to enhanced photosynthetic rate, growth and yield [139]. Moreover, it has been revealed that $P$ levels had a significant effect on plant height, branch and pod number, root and shoot dry weight, nodule number, grain, and biomass yields of lentil in a two-year trial. There has been a linear increase in root dry weight and nodule number up to $90 \mathrm{~kg} \mathrm{P}_{2} \mathrm{O}_{5} \mathrm{ha}^{-1}$, Whereas plant height, branch and pod number, shoot dry weight, grain, and biomass yields increased up to $60 \mathrm{~kg} \mathrm{P}_{2} \mathrm{O}_{5} \mathrm{ha}^{-1}$ and then decreased at $90 \mathrm{~kg} \mathrm{P}_{2} \mathrm{O}_{5} \mathrm{ha}^{-1}$ [140]. Furthermore, Srinivasarao et al. [141] signified that the response of black gram to $\mathrm{P}$ application rates in different parts of India varies from 60 to $90 \mathrm{~kg} \mathrm{P}_{2} \mathrm{O}_{5} \mathrm{ha}^{-1}$. In conformity to this result, Gulpadiya and Chhonkar [142], Neenu et al. [36], and Pingoliya et al. [143] reported that higher grain yield and yield attributes were recorded with $\mathrm{P}$ level of 60 to $90 \mathrm{~kg} \mathrm{P}_{2} \mathrm{O}_{5} \mathrm{ha}^{-1}$ for chickpea. It has been suggested that if the accessible $\mathrm{P}$ status in the soil is low to medium, the response of green gram to applied $\mathrm{P}$ was found up to $40 \mathrm{~kg} \mathrm{P}_{2} \mathrm{O}_{5} \mathrm{ha}^{-1}$ while it was only $20 \mathrm{~kg} \mathrm{P}_{2} \mathrm{O}_{5} \mathrm{ha}^{-1}$ $\mathrm{P}$ in soil testing having high level of available $\mathrm{P}$ [144]. Hence, the application of the optimum dose of $\mathrm{P}$ fertilizer has a major influence on improving the growth and productivity of legume crops including chickpea $[34,145]$.

A study illustrated that $\mathrm{P}$ levels resulted in a significant increase in growth and yield attributes of chickpea. Higher 
plant height $(102.40 \mathrm{~cm})$, branches plant ${ }^{-1}(31.10)$, and grain yield $\left(1.06 \mathrm{tha}^{-1}\right)$ were recorded in higher rate of $\mathrm{P}$ over the control, whereas increasing the $\mathrm{P}$ level from 50 to $75 \mathrm{~kg} \mathrm{P}_{2} \mathrm{O}_{5}$ $\mathrm{ha}^{-1}$ did not show any significant effect on branches plant ${ }^{-1}$ [26]. Likewise, field studies were conducted at various locations in Saskatchewan to examine chickpea response to starter $\mathrm{N}\left(0,15,30\right.$, and $\left.45 \mathrm{~kg} \mathrm{Nha}^{-1}\right)$ and $\mathrm{P}$ rates $(0,20$, and $40 \mathrm{~kg} \mathrm{P}_{2} \mathrm{O}_{5} \mathrm{ha}^{-1}$ ) using desi cv. Myles and Kabuli cv. Sanford and look at that $40 \mathrm{~kg} \mathrm{P}_{2} \mathrm{O}_{5} \mathrm{ha}^{-1}$ enhanced chickpea vegetative growth, although only desi grain yield was significantly enhanced $\left(0.12 \mathrm{tha}^{-1}\right)$ [62]. The authors suggested that the increase in chickpea yield due to $\mathrm{P}$ application apparently was due to a direct plant growth response and was not attributable to a rhizobial response, as they did not detect any notable enrichment of $\mathrm{N}_{2}$-fixation related to $\mathrm{P}$ rates. Significant increases in nodulation with $\mathrm{P}$ fertilizer rates have repeatedly been revealed as there is minute soil $\mathrm{P}$ availablity [146, 147]. A trial performed by Rehan et al. [48] indicated that plots treated with $90 \mathrm{~kg} \mathrm{Pha}^{-1}$ provided higher nodules plant ${ }^{-1}(74.00)$, plant height $(82.60 \mathrm{~cm})$, pods plant $^{-1}(50.00)$, and biological yield $\left(5.18 \mathrm{tha}^{-1}\right)$, which were statistically alike with $60 \mathrm{~kg} \mathrm{Pha}^{-1}\left(5.17 \mathrm{tha}^{-1}\right)$. Significantly higher grains $\operatorname{pod}^{-1}(1.70), 100$-grain weight $(24.86 \mathrm{~g})$, and grain yield $\left(1.45 \mathrm{tha}^{-1}\right)$ were recorded in plots treated with $60 \mathrm{~kg} \mathrm{Pha}^{-1}$. In line with this finding, an experiment showed a substantial effect of $P$ rate on growth and yield parameters except plant height and grains $\operatorname{pod}^{-1}$. Maximum and minimum (branches, shoot dry matter, pods, and grains) plant $^{-1}$ and grain and above ground biomass yields were recorded in 45 and $0 \mathrm{~kg} \mathrm{P}_{2} \mathrm{O}_{5}$ ha $^{-1}$, respectively [32]. $\mathrm{P}$ is one of the essential nutrients required in large amounts by legumes in general, and chickpea in special, for proper growth and development $[120,145]$ and yield $[25,38,145]$.

A two-year trial showed a significantly higher grain yield of chickpea (40-70\%) with P rates only in the summer sowing. Application of 45 and $90 \mathrm{~kg} \mathrm{Pha}^{-1}$ increased grain yield by $378(40.0 \%)$ and $650(69.5 \%) \mathrm{kg} \mathrm{ha}^{-1}$, sequentially against the control [148]. The increase in grain yield with $\mathrm{P}$ rate has been associated with greater crop biomass and 100grain weight at 45 and $90 \mathrm{~kg} \mathrm{Pha}{ }^{-1}$. The lack of response of grain yield to $P$ rates in winter sowing was attributed to the limited moisture received during the crop growth period. Water deficit has been indicated to limit $\mathrm{P}$ response and crop growth $[149,150]$. Thus, application of proper $\mathrm{P}$ fertilizer rate may increase grain yield and, hence, the productivity of chickpea in a given site as long as water is not limited [151]. Likewise, a study on response to $\mathrm{P}$ and Mo fertilization under irrigated conditions in chickpea revealed that the $\mathrm{P}$ rate increased stem and grain yield. $\mathrm{P}_{2} \mathrm{O}_{5}$ of 160 and $200 \mathrm{~kg} \mathrm{ha}^{-1}$ had 5.91 (stem dry matter) and $2.71 \mathrm{t} \mathrm{ha}^{-1}$ (grain) yield, consecutively [126]. Such grain yield was considered high against other countries, such as India, Pakistan, and Ethiopia with mean yield of $0.91,0.47$, and $1.91 \mathrm{tha}^{-1}$, sequentially $[152,153]$. The variation in yield level may be due to agroecological differences $[154,155]$ and/or cultivar dissimilarity of chickpea [36], especially in terms of use efficiency for $\mathrm{P}[36,156]$. The authors concluded that the area where the research was performed had high yield potential for irrigated chickpeas.
The optimum $\mathrm{P}$ rate $\left(200 \mathrm{~kg} \mathrm{ha}^{-1}\right)$ for chickpea found in such study was as well considered high as compared to other research findings [32, 48]. A field trial executed during 2011/12 to examine the effect of P levels on growth and grain yield of chickpea varieties revealed that the highest pods plant ${ }^{-1}(44.50)$, pod length $(1.38 \mathrm{~cm})$, grains plant $^{-1}$ (49.33), 100-grain weight (41.58 g), and grain yield $\left(1.69 \mathrm{tha}^{-1}\right)$ were obtained from $55 \mathrm{~kg} \mathrm{Pha}^{-1}$; however, least values were recorded in the control. D.G-92 (variety) showed its ascendancy with pods plant ${ }^{-1}(42.88)$, grains plant $^{-1}$ (47.66), pod length $(1.31 \mathrm{~cm}), 100$-grain weight $(40.79 \mathrm{~g})$, and grain yield $\left(1.56 \mathrm{tha}^{-1}\right)$ over D.G-89. Hence, it was concluded that the highest $\mathrm{P}\left(55 \mathrm{~kg} \mathrm{ha}^{-1}\right)$ contributed a maximum grain yield, while DG-92 showed its superiority over D.G-89 for all growth and yield traits [156]. A number of research findings have also revealed the varying yield performance of chickpea cultivars [36, 156-158].

\section{Effect of P Application Rate and Rhizobium Inoculation on Nodulation, Growth, and Yield Performance of Chickpea}

The proper $\mathrm{P}$ application and rhizobium inoculation are imperative to the fertility of soil due to their potential for excellent $\mathrm{N}_{2}$-fixation through rising nodulation in legumes $[48,50,120]$. Moreover, P level combined with rhizobium inoculation has been stated to raise nitrogenase activity, plant growth, grain yield of nodulated legume crops, and soil fertility $[48,159,160]$. The majority of tropical soil is particularly deficient in available $\mathrm{P}$ and in terms of appropriate and effective strains that are capable of fixing atmospheric $\mathrm{N}_{2}$, and hence, there is a need to identify an appropriate rhizobium strain that may enhance the $\mathrm{N}_{2}$-fixation attributes and yield of chickpea under different P levels [32, 161]. A number of trials have been conducted to evaluate the combined effect of $\mathrm{P}$ application rate and rhizobium inoculation under varying situations, and beneficial effects have been obtained [32, 159, 161, 162].

It has been reported that boosted $\mathrm{P}$ rates along with rhizobium increased nodules plant ${ }^{-1}$ by $31.2 \%$ over rhizobium alone [159]. Similarly, a field trial on the growth and yield response of chickpea to rhizobium strains (Thal-8, TAL-620, and their mixture $(1: 1))$ under P levels $(0,60,90$ and $120 \mathrm{~kg} \mathrm{P}_{2} \mathrm{O}_{5} \mathrm{ha}^{-1}$ ) proved that the mixture of both strains gave the most promising results and significantly increased nodulation, growth, and yield even with $60 \mathrm{~kg} \mathrm{P}_{2} \mathrm{O}_{5}$ ha $^{-1}$ while increasing the $\mathrm{P}$ dose decreased the yield [94]. It may be attributed to the improved utilization of applied nutrients with the supply of appropriate $\mathrm{N}_{2}$-fixing bacteria in the root zone. This further signified the association of rhizobium strains gained more nodules via moderate $\mathrm{P}$ application $\left(60 \mathrm{~kg} \mathrm{P}_{2} \mathrm{O}_{5} \mathrm{ha}^{-1}\right)$ over the single strain inoculated plants with the same dose of $P$ probably occurred due to poor efficiency of individual rhizobium. It has been revealed that higher nitrate reductase activity along with leghaemoglobin content was obtained from rhizobium inoculation combined with P over rhizobium alone [92]. The enrichment in leghaemoglobin content and nitrogenase 
activity of nodules by applied $\mathrm{P}$ could be ascribed to plentiful nodulation leading to increased $\mathrm{N}_{2}$-fixation. Whereas another study examined that there was a significant disparity among P levels for nodules number, the highest (24.30), which was statistically at par with the nodule number recorded in $90 \mathrm{~kg} \mathrm{P}_{2} \mathrm{O}_{5} \mathrm{ha}^{-1}$ (23.40), whereas, the lowest (14.80) nodules number were obtained from 120 to $0 \mathrm{~kg} \mathrm{P}_{2} \mathrm{O}_{5}$ $\mathrm{ha}^{-1}$, successively, but the interactions between inoculated seed and P levels were nonsignificant [163]. Besides, several studies revealed improved morphological growth resulting from inoculation and/or $\mathrm{P}$ because of increased $\mathrm{N}$ supply via BNF and through application of P $[162,164,165]$. It was observed that inoculation and $\mathrm{P}$ rates had a highly remarkable interaction effect on leaf area index (LAI); the highest (4.16) was observed under inoculated seeds $+90 \mathrm{~kg} \mathrm{P}_{2} \mathrm{O}_{5} \mathrm{ha}^{-1}$ that was statistically at par with inoculated seeds $+120 \mathrm{~kg} \mathrm{P}_{2} \mathrm{O}_{5} \mathrm{ha}^{-1}$ (4.08), whereas the lowest (1.91) was attained in uninoculated seed $+0 \mathrm{~kg} \mathrm{P}_{2} \mathrm{O}_{5}$ $\mathrm{ha}^{-1}$ [163]. An increase in LAI could be attributed to an enhanced effect of inoculation and P use on the leaf area of the crop plant. Moreover, a positive and remarkable effect of inoculation and $P$ rate was specified on branch number [166] and plant height [167] of chickpea.

A research work done to investigate the effects of rhizobium inoculation and $\mathrm{P}$ fertilizer rates on growth, yield, and yield attributes of chickpea showed a significant interaction effect of rhizobium inoculants and $\mathrm{P}_{2} \mathrm{O}_{5}$ levels on nodule number and dry weight, whereas a nonsignificant influence of treatments was observed for all growth and yield parameters [32]. Based on Wolde-Meskel et al. [161], inoculation improved nodulation, although the number of nodules varied in various years/locations in chickpea. The nodule number of 22-48 plant $^{-1}$ was recorded in the rhizobium inoculated and combined use of $\mathrm{P}$ rate and rhizobium inoculation treatments, whereas this varied from 6 to 21 in noninoculated plots (control). The authors stated that the various responses to $\mathrm{P}$ rates and inoculation across varied years/locations or individual fields are due to variations in soil properties. $\mathrm{N}_{2}$-fixation by rhizobia is known to be affected by soil characteristics such as $\mathrm{pH}$ [70] and mineral $\mathrm{N}$ content [86]; however, the effectiveness of $\mathrm{P}$ fertilizer application may be diminished by soil acidity [168]. Moreover, Singh et al. [76] signified that inoculation and P rates significantly improved nodulation, growth, and yield of chickpea compared to the control, whereas a more outstanding improvement was observed with combined use of inoculation and P. Inoculation, $\mathrm{P}$, and their combined application increased grain yield of chickpea by 26,19 , and $33 \%$, consecutively, over the control. It has also been disclosed that the rise in yield of treatments provided with inoculation and higher $\mathrm{P}$ application rates was due to an increase in yield attributes of the crop of these plots [169]. This could further the result of improved growth and development of plants due to adequate $P$ supply and its positive effect on $\mathrm{N}_{2}$-fixation. The subsequent increased $\mathrm{N}$ availability may perhaps have enhanced the provision of assimilates to seed, thereby allowing them to achieve more weight. However, a two-year trial (2014-2016) showed that coapplication of $\mathrm{P}$ and rhizobia did not result in a significant increase in the number of active nodules in bean plants during both seasons [170].

A study carried out during 2015/16 to look at the effectiveness of rhizobial inoculants (EAL 018 and EAL 029) and $\mathrm{P}$ rates $\left(0,15,30,45\right.$, and $\left.60 \mathrm{~kg} \mathrm{P}_{2} \mathrm{O}_{5} \mathrm{ha}^{-1}\right)$ on two chickpea varieties (Arerti and Habru) revealed that a significant interaction effect of rhizobium inoculants and $\mathrm{P}$ levels was reported in nodule rate. Maximum (8.04g) nodulation rate plant ${ }^{-1}$ was recorded in variety Arerti under EAL $029+45 \mathrm{~kg} \mathrm{P}_{2} \mathrm{O}_{5} \mathrm{ha}^{-1}$ followed by the same variety treated with EAL $018+30 \mathrm{~kg} \mathrm{P}_{2} \mathrm{O}_{5} \mathrm{ha}^{-1}$ [32]. This could be due to improved nodulation and healthy root system resulting from an adequate $\mathrm{P}$ supply and effective rhizobium colonization in the root zone for successful $\mathrm{N}_{2}$-fixation. The authors suggested that Arerti inoculated with EAL $029+45 \mathrm{~kg} \mathrm{P}_{2} \mathrm{O}_{5} \mathrm{ha}^{-1}$ to be suitable for chickpea production in the study area and the use of $\mathrm{P}_{2} \mathrm{O}_{5}$ with rhizobium inoculation as a nutrient management strategy could increase chickpea production. A trial was conducted on-station to scrutinize the growth, nodulation, and yield responses of groundnut varieties (Obolo, Oboshie, and Samnut 22) to rhizobium inoculation (BR 3267 and USDA 3456) and P levels $\left(0,15\right.$, and $\left.30 \mathrm{~kg} \mathrm{Pha}^{-1}\right)$ indicated that coupled use of $30 \mathrm{~kg} \mathrm{Pha}^{-1}$ and BR 3267 increased nodule numbers in Obolo (144\%), Oboshie (188\%), and Samnut 22 (56\%) and pod yield (64-68\%) over the control [171]. Application of rhizobium inoculants assists in increasing the nodules plant $^{-1}$ which successively contributes to adequate $\mathrm{N}$ supply via effective $\mathrm{N}_{2}$-fixation with the addition of $\mathrm{P}$ fertilizer and ultimately gives rise to boost growth and yield [172]. In conformity to the above findings, the research work executed by Mmbaga et al. [173] divulged that legumes inoculated with rhizobium in addition to $\mathrm{P}$ fertilizer responded differently regarding growth, yield, and $\mathrm{N}_{2}$-fixation.

In a trial executed to evaluate the effect of P levels $(30,60$, and $90 \mathrm{~kg} \mathrm{ha}^{-1}$ ), rhizobium inoculation (inoculated and uninoculated seeds), and residue types (cereal, legumes, and oilseeds) on chickpea productivity revealed that the highest $\left(1.55\right.$ and $\left.5.36 \mathrm{tha}^{-1}\right)$ grain and biological yields were obtained under inoculated seeds $+60 \mathrm{~kg} \mathrm{Pha}^{-1}$, whereas the lowest (1.22 and $4.88 \mathrm{tha}^{-1}$ ) grain and biological yields were recorded in uninoculated seeds $+30 \mathrm{~kg} \mathrm{Pha}^{-1}$ [48]. Besides, a different study on the interaction between seed inoculation and $\mathrm{P}$ levels showed considerable variation among treatments for yield and its attributes. Highest (3.09 and $7.50 \mathrm{tha}^{-1}$ ) and lowest (1.60 and $4.34 \mathrm{tha}^{-1}$ ) grain and biological yields were recorded in inoculated seeds $+90 \mathrm{~kg} \mathrm{P}_{2} \mathrm{O}_{5} \mathrm{ha}^{-1}$ and uninoculated seeds $+0 \mathrm{~kg} \mathrm{P}_{2} \mathrm{O}_{5}$ $\mathrm{ha}^{-1}$, respectively. The lowest yield in the control was due to low plant height, less yield, and its attributes [163]. WoldeMeskel et al. [161] studied the responses of chickpea to inoculation (I) and $\mathrm{P}$ rates (P) from extensive trials on smallholder farmers' fields over four regions of Ethiopia and revealed that increased grain yields were due to I and P + I and were obvious for $99 \%$ of selected farmers. Nearly, I and P increased grain yield by 21 and 25\%, serially; yet the combined use of I and P provided a 38\% increase over the control plots. However, recorded grain yields on control plots and responses to the treatments on single farms varied 
markedly. This may have resulted from the optimistic effects of $\mathrm{P}$ on the course of $\mathrm{N}_{2}$-fixation, where the boosted supply of $\mathrm{N}$ by means of inoculation contributed to enhanced plant growth that ultimately leads to $\mathrm{P}$ insufficiency. It has been concluded by other authors that the integrated use of $\mathrm{P}$ and rhizobium inoculation boosted nitrogenase activity, growth, and grain yield along with improved soil fertility for sustained agricultural production $[162,174]$.

A study demonstrated that the use of $60 \mathrm{~kg} \mathrm{Pha}^{-1}$, $20 \mathrm{~kg} \mathrm{Sha}^{-1}$ and seed inoculation with PSB + rhizobium considerably increased growth, dry weight, nodules plant ${ }^{-1}$, and grain and straw yields of chickpea over the uninoculated ones [76]. The use of optimum fertilizer rate and biofertilizers could enhance the growth and yield performance of the crop. A two-year trial on growth, symbiotic, and grain yield response of bean plants to rhizobial inoculation (uninoculated, inoculated with strain HB-429 or GT-9) and P levels $\left(0,10,20\right.$, and $\left.30 \mathrm{~kg} \mathrm{Pha}^{-1}\right)$ revealed that the interaction of rhizobium and $\mathrm{P}$ was significant for shoot dry matter and grain yield. Greater shoot biomass was found in inoculated plants over uninoculated ones in 0,10 , and $30 \mathrm{~kg} \mathrm{Pha}^{-1}$ in both years. At $20 \mathrm{~kg} \mathrm{Pha}{ }^{-1}$, the shoot biomass produced by uninoculated and strain GT- 9 inoculated plants were similar in both years, but lower than those of strain HB429 perhaps resulting from the variation in efficiency of the distinct rhizobium strains [133]. A study conducted during 2015/2016 in a greenhouse to evaluate the effect of rhizobium inoculation and couple of $\mathrm{P}$ and $\mathrm{N}$ rates on the growth and yield of groundnut showed that the highest plant height $(75.00 \mathrm{~cm})$, branches plant ${ }^{-1}(21.30)$, nodules plant ${ }^{-1}$ (45.00), pods plant ${ }^{-1}(18.30)$, pod yield $\left(2.66 \mathrm{tha}^{-1}\right)$, and 100 -grain weight $(39.20 \mathrm{~g})$ were observed in rhizobium inoculated treatments under the recommended $\mathrm{P}$ and $\mathrm{N}$ rates [175]. The authors cautiously concluded that groundnut seeds inoculated with rhizobium and fertilized at $82 \mathrm{~kg} \mathrm{P}_{2} \mathrm{O}_{5}$ $\mathrm{ha}^{-1}$ and $27 \mathrm{~kg} \mathrm{Nha}^{-1}$, during the growth stage, showed improved growth and yield and its attributes. In line with the above findings, it has been disclosed that $\mathrm{N}$ application as a starter dosage along with $\mathrm{P}$ and seed inoculation has a useful effect on the yield of chickpea [176]. It was reported that dual use of $\mathrm{P}$ at $45 \mathrm{~kg} \mathrm{ha}^{-1}$ plus rhizobium inoculants improved nodulation by $56 \%$ and recorded significantly higher grain yields in soybean. This work further confirmed that the coupled application of $\mathrm{P}$ at $45 \mathrm{~kg} \mathrm{ha}^{-1}$ and rhizobium inoculants was more cost-effective than the use of only $45 \mathrm{~kg} \mathrm{Pha}^{-1}$ [177]. Several research findings have well demonstrated the significant effect of $P$ rates integrated with rhizobium inoculation on nodulation, growth, and yield performance of legume crops such as lentil [163], field pea [140], soybean [178], and beans [133, 170].

\section{Conclusion}

Chickpea is among the most significant food legumes that are used as a source of food and feed, cash income for farmers, and in sustaining soil fertility. However, its productivity has been declined probably due to P-deficiency and the usual native soil rhizobial populations are insufficient/ ineffective in N2-fixation. To supply adequate rhizobial population in the rhizosphere, seed inoculation with an effective and importunate rhizobial strain is essential for chickpea in soils having no/feeble bacterial existence. In this regard, rhizobium inoculation of the seed may substitute costly $\mathrm{N}$-fertilizers and is a useful way of achieving sustainable production. Moreover, chickpea has high demand for P for effective N2-fixation, growth, and yield. Hence, the objective of this paper is to review the effect of $\mathrm{P}$ rate and rhizobium inoculation on nodulation, growth and yield performance of chickpea. Various research reports showed an optimistic effect of rhizobium inoculation on nodulation (nodule number and mass), growth, yield, and its components of chickpea over uninoculated ones; this has been influenced by mineral $\mathrm{N}$ content and P-deficiency of soil, rhizobium strain, variety, $\mathrm{pH}$, salinity, and moisture stress. Several findings revealed that $\mathrm{P}$ rates $\left(30-200 \mathrm{~kg} \mathrm{P}_{2} \mathrm{O}_{5} \mathrm{ha}^{-1}\right)$ had significant effects on N2-fixation (nodule number, mass, and rating plant ${ }^{-1}$ ), growth (LA, RGR, DM, plant height, and branches plant ${ }^{-1}$ ) and yield and its attributes (pods and grains plant ${ }^{-1}$, grain and BM yields, 100-grain weight and $\mathrm{HI}$ ) compared to the control. P rate response of chickpea has been affected by moisture level, $\mathrm{pH}$, availability of $\mathrm{P}$ and $\mathrm{N}$, and variety. Particularly, a joint use of $\mathrm{P}$ rate and rhizobium inoculation on chickpea has been stated to improve nodulation, growth, and yield and soil fertility. Various studies on the integrated use of $\mathrm{P}$ rate and rhizobium inoculation under varied situations showed substantial effects (enhanced nodulation, growth, yield, and its attributes) over the separate use of $\mathrm{P}$ rate or rhizobium inoculation. This might be attributed to adequate $\mathrm{P}$ supply and its optimistic effects on the process of N2-fixation (nodulation), successful colonization of the root surface by effective rhizobial strains (increased $\mathrm{N}$ supply), and growth and development contributing to increased yield. Hence, it has been suggested that the use of $\mathrm{P}\left(\mathrm{P}_{2} \mathrm{O}_{5}\right)$ along with rhizobium inoculation could be used as a nutrient management strategy for increased and sustained chickpea production.

\section{Conflicts of Interest}

The authors declare that there are no conflicts of interest regarding the publication of this paper.

\section{Authors' Contributions}

Both authors significantly contributed to this review paper. Mebrahtu Gebremariam intensively devoted his time in developing this review paper in a well-articulated way.

\section{Acknowledgments}

The authors greatly acknowledge the Aksum University Shire Campus for the facilities provided to develop this review article.

\section{References}

[1] R. J. Redden and J. D. Berger, "History and origin of chick pea," in Chick Pea Breeding and Management, B. Sharma, 
S. S. Yadav, and W. Chen, Eds., pp. 1-13, CABI Walling ford, Wallingford, UK, 2007.

[2] L. J. G. van der Maesen, "Origin, history and taxonomy of Chickpea," in The Chickpea, M. C. Saxena and K. B. Singh, Eds., pp. 11-34, C.A.B. International, Wallingford, UK, 1987.

[3] L. Lopez-Bellido, M. Fuentes, J. E. Castillo, F. J. LopezGarrido, and E. J. Fernandez, "Long-term tillage, crop rotation, and nitrogen fertilizer effects on wheat yield under rainfed Mediterranean conditions," Agronomy Journal, vol. 88, no. 5, pp. 783-791, 1996.

[4] FAO (Food and Agriculture Organization of the United Nations), Production of Chickpea by Countries, Food and Agriculture Organization of the United Nations, Rome, Italy, 2014.

[5] F. Singh and B. Diwakar, "Chickpea botany and production practices," Skill Development Series, vol. 16, pp. 8-9, 1995.

[6] L. K. Tripathi, T. Thomas, V. J. Singh, S. Gampala, and R. Kumar, "Effect of nitrogen and phophorus application on soil nutrient balance in chickpea (Cicer arietinum L.) cultivation," Green Farming, vol. 6, no. 2, pp. 319-322, 2015.

[7] FAO (Food and Agriculture Organization), FAOSTAT Statistical Database of the United Nation Food and Agriculture Organization, (FAO) Statistical Division, Rome, Italy, 2019.

[8] M. Erman, S. Demir, E. Ocak, Ş. Tüfenkçi, F. Oğuz, and A. Akköprü, "Effects of Rhizobium, arbuscular mycorrhiza and whey applications on some properties in chickpea (Cicer arietinum L.) under irrigated and rainfed conditions 1-yield, yield components, nodulation and AMF colonization," Field Crops Research, vol. 122, no. 1, pp. 14-24, 2011.

[9] D. Werner and W. E. Newton, Nitrogen Fixation in Agriculture, Forestry, Ecology and the Environment, Vol. 4, Springer, Dordrecht, Netherlands, 2005.

[10] N. Togay, Y. Togay, K. M. Cimrin, and M. Turan, "Effects of rhizobium inoculation, sulfur and phosphorus applications on yield, yield components and nutrient uptakes in chickpea (Cicer arietinum L.)," African Journal of Biotechnology, vol. 7, no. 6, pp. 776-782, 2008.

[11] J. A. Wood and M. A. Grusak, Chickpea Breeding and Management, S. S. Yadav, B. Redden, W. Chen, and B. Sharma, Eds., pp. 101-142, CAB International, Wallingfordm UK, 2007.

[12] M. Uddin, S. Hussain, M. M. A. Khan et al., "Use of N and P biofertilizers reduces inorganic phosphorus application and increases nutrient uptake, yield, and seed quality of chickpea," Turkish Journal of Agriculture and Forestry, vol. 38, pp. 47-54, 2014.

[13] A. Funga, O. Chris, O. C. Ojiewo, L. Turoop, and S. G. Githiri Stephen Mwangi, "Symbiotic effectiveness of elite rhizobia strains nodulating desi type chickpea (Cicer arietinum L.) varieties," Journal of Plant Sciences, vol. 4, no. 4, pp. 88-94, 2016.

[14] B. Khaitov, A. Kurbonov, A. Abdiev, and M. Adilov, "Effect of chickpea in association with Rhizobium to crop productivity and soil fertility," Eurasian Journal of Soil Science (EJSS), vol. 5, no. 2, pp. 105-112, 2016.

[15] V. Shurigin, K. Davranov, and A. Abdiev, "Screening of salt tolerant rhizobia for improving growth and nodulation of chickpea (Cicer arietinum) under arid soil conditions of Uzbekistan," Journal of Biological and Chemical Research, vol. 32, no. 2, pp. 534-540, 2015.

[16] G. Selvakumar, S. Reetha, and P. Thamizhiniyan, "Response of biofertilizers on growth, yield attributes and associated protein profiling changes of blackgram (Vigna mungo
L. Hepper)," World Applied Sciences Journal, vol. 16, no. 10, pp. 1368-1374, 2012.

[17] B. Merga and J. Haji, "Economic importance of chickpea: production, value, and world trade," Cogent Food \& Agriculture, vol. 5, no. 1, Article ID 1615718, 2019.

[18] A. Fikre, "Progresses of chickpea research and development in Ethiopia," in Harnessing Chickpea Value Chain for $\mathrm{Nu}$ trition Security and Commercialization of Smallholder Agriculture in Africa, Proceedings of a Workshop, $30^{\text {th }}$ January- $1^{\text {st }}$ Feburary, 2014, L. Korbu, T. Damte, and A. Fikre, Eds., pp. 25-39, Debre Zeit, Bishoftu, Ethiopia, 2016.

[19] M. Latati, S. Benlahrech, M. Lazali et al., "Intercropping promotes the ability of legume and ccereal to facilitate phosphorus and nitrogen acquisition through root-induced processes," in Grain Legumes, A. K. Goyal, Ed., pp. 127-139, E-Publishing Intech, Rijeka, Croatia, 2016.

[20] I. S. Naruka, K. D. Gujar, and G. Lal, "Effect of foliar application of zinc and molybdenum on growth and yield of okra (Abelmoschus esculentus L. Moench) cv. Pusa sawani," Haryana Journal of Horticultural Sciences, vol. 29, no. 3/4, pp. 266-267, 2000.

[21] D. L. Rudresh, M. K. Shivaprakash, and R. D. Prasad, "Effect of combined application of Rhizobium, phosphate solubilizing bacterium and Trichoderma spp. on growth, nutrient uptake and yield of chickpea (Cicer aritenium L.)," Applied Soil Ecology, vol. 28, no. 2, pp. 139-146, 2005.

[22] A. Ali, Z. Ali, J. Iqbal et al., "Impact of nitrogen and phosphorus on seed yield of chickpea," Journal of Agricultural Sciences, vol. 48, no. 3, pp. 335-338, 2010.

[23] K. Mohammadi, A. Ghalavand, M. Aghaalikhani, G. Heidari, and Y. Sohrabi, "Introducing a sustainable soil fertility system for chickpea (Cicer arietinum L.)," African Journal of Biotechnology, vol. 10, no. 32, pp. 6011-6020, 2011.

[24] H. Yakubu, J. D. Kwari, and M. K. Sandabe, "Effect of phosphorus fertilizer on nitrogen fixation by some grain legume varieties in Sudano-Sahelian zone of north eastern Nigeria," Nigerian Journal Basic Applied Science, vol. 18, no. 1, pp. 19-26, 2010

[25] G. S. Yadav, S. Babu, R. S. Meena et al., "Effects of godawariphos gold and single supper phosphate on groundnut (Arachis hypogaea) productivity, phosphorus uptake, phosphorus use efficiency and economics," Indian Journal of Agricultural Science, vol. 87, no. 9, pp. 1165-1169, 2017.

[26] M. Memon, A. N. Rajput, A. Rajput, N. Memon, G. M. Jamro, and M. I. Kumbhar, "Response of chickpea cultivars to phosphorus application," Soil and Environment, vol. 35, no. 1, pp. 22-29, 2016.

[27] S. B. Sharma, R. Z. Sayyed, M. H. Trivedi, and T. A. Gobi, "Phosphate solubilizing microbes: sustainable approach for managing phosphorus deficiency in agricultural soils," SpringerPlus, vol. 2, p. 587, 2013.

[28] G. Gidago, S. Beyene, and W. Worku, "Response of haricot bean (Phaseolus vulgaris L.) to phosphorus application on Ultisols at Areka, Southern Ethiopia," Journal of Biology, Agriculture and Healthcare, vol. 1, no. 3, pp. 38-49, 2012.

[29] L. H. Green and G. Shama, "Basic cell biology," in Plasma Medicine -applications of Low Temperature Gas Plasmas in Medicine and Biology, M. Laroussi, Ed., p. 7598, Cambridge University Press, Cambridge, UK, 2012.

[30] B. Griffith, Efficient Fertilizer Use-Phosphorus, McMillan Co., Amsterdam, Netherlands, 2010.

[31] E. B. Santana, E. L. Marques, and J. C. Dias, "Effects of phosphate-solubilizing bacteria, native microorganisms, and 
rock dust on Jatropha curcas L. growth," Genetics and Molecular Research: GMR, vol. 15, no. 4, 2016.

[32] T. Meleta and G. Abera, "Effects of rhizobium inoculation and phosphorus fertilizer rates on nitrogen fixation and nutrient up take of chickpea (Cicer arietinum L.) at Goro, Bale zone, Oromia regional state," Greener Journal of Agricultural Sciences, vol. 9, no. 4, pp. 436-446, 2019.

[33] D. A. D. Silva, J. A. D. F. Esteves, U. Messias et al., "Efficiency in the use of phosphorus by common bean genotypes," Scientia Agricola, vol. 71, no. 3, pp. 232-239, 2014.

[34] T. Mitran, R. S. Meena, R. Lal, J. Layek, S. Kumar, and R. Datta, "Role of soil phosphorus on legume production," in Legumes for Soil Health and Sustainable ManagementSpringer, Singapore, 2018.

[35] J. B. O. Ogola and N. Thangwana, "Water use efficiency of summers sown chickpea in a tropical environment: response to genotype and planting density," Journal of Food, Agriculture and Environment, vol. 11, pp. 2689-2695, 2013.

[36] S. Neenu, K. Ramesh, S. Ramana, A. K. Biswas, and A. R. Subba, "Growth and yield of different varieties of chickpea (Cicer arietinum L.) as influenced by the phosphorus nutrition under rainfed conditions on vertisols," International Journal of Bio-Resource and Stress Management, vol. 5, no. 1, pp. 53-57, 2014.

[37] A. R. Sanchez-Rodriguez, M. C. Del Campillo, J. Torrent, and D. L. Jones, "Organic acids alleviate iron chlorosis in chickpea grown on two P-fertilized soils," Journal of Soil Science and Plant Nutrition, vol. 14, no. 2, pp. 292-303, 2014.

[38] K. Balai, Y. M. Sharma, M. Jajoria, D. Parvati, and V. Rinkee, "Effect of phosphorus, and zinc on growth, yield and economics of chickpea (Cicer arietinum L.)," International Journal of Current Microbiology and Applied Sciences, vol. 6, no. 3, pp. 1174-1181, 2017.

[39] R. L. Yadav, B. S. Dwivedi, K. Prasad, O. K. Tomar, N. J. Shurpali, and P. S. Pandey, "Yield trends, and changes in soil organic-C and available NPK in a long-term rice-wheat system under integrated use of manures and fertilisers," Field Crops Research, vol. 68, no. 3, pp. 219-246, 2000.

[40] B. Singh, "Are nitrogen fertilizers deleterious to soil health?" Agronomy, vol. 8, no. 4, p. 48, 2018.

[41] J. W. Erisman, M. A. Sutton, J. Galloway, Z. Klimont, and W. Winiwarter, "How a century of ammonia synthesis changed the world," Nature Geoscience, vol. 1, no. 10, pp. 636-639, 2008.

[42] T. Jagadish, "Can organic sources of nutrients increase crop yields to meet global food demand? Review," Agronomy, vol. 8 , no. 10, p. $214,2018$.

[43] U. Kremser and E. Schnug, "Impact of fertilizers on aquatic ecosystems and protection of water bodies from mineral nutrients," Landbauforschung Völkenrode, vol. 2, no. 52, pp. 81-90, 2002.

[44] S. C. Wagner, "Biological nitrogen fixation," 'Nature Education Knowledge, vol. 3, no. 10, p. 15, 2011.

[45] P. E. Courty, P. Smith, S. Koegel, D. Redecker, and D. Wipf, "Inorganic nitrogen uptake and transport in beneficial plant root-microbe interactions," Critical Reviews in Plant Sciences, vol. 34, no. 1-3, pp. 4-16, 2015.

[46] K. Mohammadi and Y. Sohrabi, "Bacterial biofertilizers for sustainable crop production: a review," ARPN Journal of Agricultural and Biologcal Science, vol. 7, no. 5, pp. 307-316, 2012.

[47] G. E. Oldroyd and R. Dixon, "Biotechnological solutions to the nitrogen problem," Current Opinion in Biotechnology, vol. 26, pp. 19-24, 2014.
[48] W. Rehan, A. Jan, W. Liaqat et al., "Effect of phosphorous, rhizobium inoculation and residue types on chickpea productivity," Pure and Applied Biology, vol. 7, no. 3, 2018.

[49] D. Egamberdieva, V. Shurigin, S. Gopalakrishnan, and R. Sharma, "Growth and symbiotic performance of chickpea (Cicer arietinum) cultivars under saline soil conditions," Journal of Biological and Chemical Research, vol. 31, no. 1, pp. 333-341, 2014.

[50] T. Suzaki, E. Yoro, and M. Kawaguchi, "Leguminous plants: inventors of root nodules to accommodate symbiotic bacteria," International Review of Cell and Molecular Biology, vol. 316, pp. 111-158, 2015.

[51] H. Korir, N. W. Mungai, M. Thuita, Y. Hamba, and C. Masso, "Co-inoculation effect of rhizobia and plant growth promoting rhizo bacteria on common bean growth in a low phosphorus soil," Frontiers in Plant Science, vol. 8, no. 141, 2017.

[52] M. Unkovich, D. Herridge, M. Peoples et al., Measuring Plant Associated Nitrogen Fixation in Agricultural Systems, Australian Centre for International Agricultural Research, Canberra, Australia, 2008.

[53] I. Papastylianou, "The role of legumes in agricultural production in Cyprus," in Nitrogen Fixation by Legumes in Mediterranean Agriculture, D. P. Beck and L. A. Materon, Eds., Martinus Nijhoff Publishers, Dordrecht, Netherlands, pp. 55-63, 1988.

[54] N. Sanginga, G. Thottappilly, and K. Dashiell, "Effectiveness of rhizobia nodulating recent promiscuous soyabean selections in the moist savanna of Nigeria," Soil Biology and Biochemistry, vol. 32, no. 1, pp. 127-133, 2000.

[55] G. Hardarson and C. Atkins, "Optimising biological N2 fixation by legumes in farming systems," Plant and Soil, vol. 252, no. 1, pp. 41-54, 2003.

[56] F. L. Walley, G. W. Clayton, P. R. Miller, P. M. Carr, and G. P. Lafond, "Nitrogen economy of pulse crop production in the northern great plains," Agronomy Journal, vol. 99, no. 6, pp. 1710-1718, 2007.

[57] J. Y. Yang, C. F. Drury, X. M. Yang et al., "Estimating biological N2 fixation in Canadian agricultural land using legume yields," Agriculture, Ecosystems \& Environment, vol. 137, no. 1-2, pp. 192-201, 2010.

[58] M. Kermah, A. C. Franke, S. Adjei-Nsiah, B. D. K. Ahiabor, R. C. Abaidoo, and K. E. Giller, "N2-fixation and N contribution by grain legumes under different soil fertility status and cropping systems in the Guinea savanna of northern Ghana," Agriculture, Ecosystems \& Environment, vol. 261, pp. 201-210, 2018.

[59] E. T. Kiers, R. A. Rousseau, S. A. West, and R. F. Denison, "Host sanctions and the legume-rhizobium mutualism," Nature, vol. 425, no. 6953, pp. 78-81, 2003.

[60] F. Kantar, F. Y. Hafeez, B. G. Shivakumar et al., "Chickpea: rhizobium management and nitrogen fixation," in Chickpea Breeding and Management, S. S. Yadav, R. Redden, W. Chen et al., Eds., pp. 179-192, CABI, Wallingford, UK, 2007.

[61] P. M. Chalk, B. J. R. Alves, R. M. Boddey, and S. Urquiaga, "Integrated effects of abiotic stresses on inoculant performance, legume growth and symbiotic dependence estimated by $15 \mathrm{~N}$ dilution," Plant and Soil, vol. 328 , no. 1-2, pp. 1-16, 2010.

[62] F. L. Walley, S. Kyei-Boahen, G. Hnatowich, and C. Stevenson, "Nitrogen and phosphorus fertility management for desi and kabuli chickpea," Canadian Journal of Plant Science, vol. 85, no. 1, pp. 73-79, 2005. 
[63] S. Caliskan, I. Ozkaya, M. E. Caliskan, and M. Arslan, "The effects of nitrogen and iron fertilization on growth, yield and fertilizer use efficiency of soybean in a Mediterranean-type soil," Field Crops Research, vol. 108, no. 2, pp. 126-132, 2008.

[64] F. Salvagiotti, K. G. Cassman, J. E. Specht, D. T. Walters, A. Weiss, and A. Dobermann, "Nitrogen uptake, fixation and response to fertilizer $\mathrm{N}$ in soybeans: a review," Field Crops Research, vol. 108, no. 1, pp. 1-13, 2008.

[65] J. Kumar and S. Abbo, "Genetics of flowering time in chickpea and its bearing on productivity in semiarid environments," Advances in Agronomy, vol. 72, pp. 107-138, 2001.

[66] D. P. Beck, J. Wery, M. C. Saxena, and A. Ayadi, "Dinitrogen fixation and nitrogen balance in cool-season food legumes," Agronomy Journal, vol. 83, no. 2, pp. 334-341, 1991.

[67] D. P. Beck, "Yield and nitrogen fixation of chickpea cultivars in response to inoculation with selected rhizobial strains," Agronomy Journal, vol. 84, no. 3, pp. 510-516, 1992.

[68] E. V. Tairo and P. A. Ndakidemi, "Possible benefits of rhizobial inoculation and phosphorus supplementation on nutrition, growth and economic sustainability in grain legumes," American Journal of Research Communication, vol. 1, no. 12, pp. 532-556, 2013.

[69] R. J. López-Bellido, L. López-Bellido, J. Benítez-Vega, V. Muñoz-Romero, F. J. López-Bellido, and R. Redondo, "Chickpea and faba bean nitrogen fixation in a Mediterranean rainfed Vertisol: effect of the tillage system," European Journal of Agronomy, vol. 34, no. 4, pp. 222-230, 2011.

[70] G. N. Cheminingwa and J. K. Vessey, "The abundance and efficacy of rhizobium leguminosarum bv. viciae in cultivated soils of the eastern Canadian prairie," Soil Biolology and Biochemistry, vol. 38, no. 2, pp. 294-302, 2006.

[71] E. Pellegrino and S. Bedini, "Enhancing ecosystem services in sustainable agriculture: biofertilization and biofortification of chickpea (Cicer arietinum L.) by arbuscular mycorrhizal fungi," Soil Biology and Biochemistry, vol. 68, pp. 429-439, 2014.

[72] C. Carranca, A. De Varennes, and D. Rolston, "Biological nitrogen fixation by fababean, pea and chickpea, under field conditions, estimated by the isotope dilution technique," European Journal of Agronomy, vol. 10, no. 1, pp. 49-56, 1999.

[73] F. Kantar, B. G. Shivakumar, C. Arrese-Igor et al., "Efficient biological nitrogen fixation under warming climates," in Climate Change and Management of Cool Season Grain Legume Crops, S. S. Yadav, D. L. McNeil, R. Redden, and S. A. Patil, Eds., Springer, New York, NY, USA, pp. 283-306, 2010.

[74] G. Catroux, A. Hartmann, and C. Revellin, "Trends in rhizobial inoculants production and use," Plant and Soil, vol. 230, no. 1, pp. 21-30, 2001.

[75] A. Getachew and F. Rezone, Response of Faba Bean to Phosphate Fertilizer and Weed Control on Nitsols of Ethiopian Highlands, Holeta Agricultural Research Center, EARO, Holeta Genet, Ethiopia, 2006.

[76] R. Singh, T. Pratap, D. Singh, G. Singh, and A. K. Singh, "Effect of phosphorus, sulphur and biofertilizers on growth attributes and yield of chickpea (Cicer arietinum L.)," Journal of Pharmacognosy and Phytochemistry, vol. 7, no. 2, pp. 3871-3875, 2018.

[77] A. S. F. Araujo, M. V. B. Figueiredo, and R. T. R. Monteiro, Nitrogen Fixation Research Progress, Nova Science Publishers, Brazil, 2008.
[78] B. R. Glick, "Plant growth-promoting bacteria: mechanisms and applications," Scientifica, vol. 2012, Article ID 963401, 15 pages, 2012.

[79] O. P. Rupela and M. C. Saxena, "Nodulation and nitrogen fixation in chickpea," in The Chickpea, M. C. Saxena and K. B. Singh, Eds., pp. 191-206, CAB International, Wallingford, UK, 1987.

[80] E. F. Henzell, "The role of biological nitrogen fixation research in solving problems in tropical agriculture," Plant and Soil, vol. 108, no. 1, pp. 15-21, 1988.

[81] T. Geletu and F. Mekonnen, "The effect of bio and inorganic fertilizer on yield, nutrient uptake and economics of mungbean (Vigna radiata L. Wilczek) varieties in Ethiopia," Journal of Agricultural Research, vol. 3, no. 11, Article ID 000212, 2018.

[82] A. C. Rebeschini, R. C. L. Mazzuchelli, A. S. F. Araujo, and F. F. Araujo, "Nitrogen application and inoculation with rhizobium tropici on common bean in the fall/winter," African Journal of Agricultural Research, vol. 9, no. 42, pp. 3156-3163, 2014.

[83] X. Xia, C. Ma, S. Dong, Y. Xu, and Z. Gong, "Effects of nitrogen concentrations on nodulation and nitrogenase activity in dual root systems of soybean plants," Soil Science and Plant Nutrition, vol. 63, no. 5, pp. 470-482, 2017.

[84] C.-W. Liu and J. D. Murray, "The role of flavonoids in nodulation host-range specificity: an update," Plants (Basel), vol. 5, no. 3, p. 33, 2016.

[85] J. Brockwell, R. Gault, L. Morthorpe, M. Peoples, G. Turner, and F. Bergersen, "Effects of soil nitrogen status and rate of inoculation on the establishment of populations of Bradyrhizobium japonicum and on the nodulation of soybeans," Australian Journal of Agricultural Research, vol. 40, no. 4, pp. 753-762, 1989.

[86] G. Kamble, G. K. Giri, A. M. Charpe, and P. S. Wakte, "Effect of nitrogen doses with rhizobium seed inoculation on nodulation and grain yield of chickpea," 2019.

[87] A. Argaw and A. Akuma, "Rhizobium leguminosarum bv. viciae sp. inoculation improves the agronomic efficiency of $\mathrm{N}$ of common bean (Phaseolus vulgaris L.)," Environmental Systems Research, vol. 4, no. 11, 2015.

[88] K. E. Giller and G. Cadisch, "Future benefits from biological nitrogen fixation: an ecological approach to agriculture," Plant and Soil, vol. 174, no. 1-2, pp. 255-277, 1995.

[89] S. Singh, S. S. Bawa, S. Singh, S. C. Sharma, and P. Sheoran, "Productivity, profitability and sustainability of rain-fed chickpea under inorganic and biofertilization in foothills of north-west Himalayas," Archives of Agronomy and Soil Science, vol. 61, no. 8, pp. 1151-1163, 2015.

[90] M. Aslam Avais, N. Ahmad, M. Rafique et al., "Effectiveness of bacterial inoculation for improving grain yield and quality of chickpea," Soil \& Environment, vol. 36, no. 2, pp. 190-196, 2017.

[91] J. Yadav and J. P. Verma, "Effect of seed inoculation with indigenous Rhizobium and plant growth promoting rhizobacteria on nutrients uptake and yields of chickpea (Cicer arietinum L.)," European Journal of Soil Biology, vol. 63, pp. 70-77, 2014.

[92] D. Moinuddin, T. A. Hussain, S. Khan et al., "Use of N and P biofertilizers together with phosphorus fertilizer improves growth and physiological attributes of chickpea," Global Journal of Agricultural Sciences, vol. 2, pp. 168-174, 2014.

[93] J. P. Verma, J. Yadav, K. N. Tiwari, and A. Kumar, "Effect of indigenous Mesorhizobium spp. and plant growth promoting rhizobacteria on yields and nutrients uptake of 
chickpea (Cicer arietinum L.) under sustainable agriculture,” Ecological Engineering, vol. 51, pp. 282-286, 2013.

[94] M. Aslam, I. A. Mahmood, T. Sultan, S. Ahmad, and M. A. Zahid, "Growth and yield response of chickpea (Cicer arientinum) to rarious rhizobium strains fertilized with different phosphorus levels," International Journal of Agriculture and Biology, vol. 2, no. 1-2, pp. 89-91, 2000.

[95] J. D. Berger, M. Ali, P. S. Basu et al., "Genotype by environment studies demonstrate the critical role of phenology in adaptation of chickpea (Cicer arietinum L.) to high and low yielding environments of India," Field Crops Research, vol. 98, no. 2, pp. 230-244, 2006.

[96] R. G. H. Khan, N. U. Khan, and F. U. Khan, "Characterization of chickpea germplasm for nodulation and effect of rhizobium inoculation on nodules number and seed yield," The Journal of Animal and Plant Sciences, vol. 24, no. 5, pp. 1421-1429, 2014.

[97] J. B. O. Ogola, "Growth and yield response of chickpea to Rhizobium inoculation: productivity in relation to interception of radiation," Legume Research, vol. 38, no. 6, pp. 837-843, 2015.

[98] B. R. Samir, T. Mustapha, E. A. Mohamed, L. Philippe, and M. Ridha, "the diversity of rhizobia nodulating chickpea (Cicer arietinum) under water deficiency as a source of more efficient inoculants," Soil Biology and Biochemistry, vol. 41, pp. 2568-2572, 2009.

[99] S. Kyei-Boahen, A. E. Slinkard, and F. L. Walley, "Evaluation of rhizobial inoculation methods for chickpea," Agronomy Journal, vol. 94, no. 4, pp. 851-859, 2002.

[100] G. Nishita and N. C. Joshi, "Growth and yield response of chick pea (Cicer arietinum) to seed inoculation with Rhizobium sp," Nature and Science, vol. 8, no. 9, pp. 232-236, 2010.

[101] S. J. Geetha and S. J. Joshi, "Engineering rhizobial bioinoculants: a strategy to improve iron nutrition, review article," The Scientific World Journal, vol. 2013, Article ID 315890, 15 pages, 2013.

[102] G. Singh, H. S. Sekhon, and P. Sharma, "Effect of irrigation and biofertilizer on water use, nodulation, growth and yield of chickpea (Cicer arietinum L.)," Archives of Agronomy and Soil Science, vol. 57, no. 7, pp. 715-726, 2011.

[103] M. A. H. Bhuiyan, D. Khanam, M. F. Hossain, and M. S. Ahmed, "Effect of rhizobium inoculation on nodulation and yield of chickpea in calcareous soil," Bangladesh Journal of Agricultural Research, vol. 33, no. 3, pp. 549-554, 2008.

[104] F. A. Salih, "Chickpea cultivars X rhizobium interaction in northern Sudan," International Chickpea News Letter, vol. 10, pp. 22-24, 1984.

[105] A. Namvar, R. S. Sharifi, M. Sedghi, R. A. Zakaria, T. Khandan, and B. Eskandarpour, "Study on the effects of organic and inorganic nitrogen fertilizer on yield, yield components, and nodulation state of chickpea (Cicer arietinum L.)," Communications in Soil Science and Plant Analysis, vol. 42, no. 9, pp. 1097-1109, 2011.

[106] W. Tena, E. Wolde-Meskel, and F. Walley, "Response of chickpea (Cicer arietinum L.) to inoculation with native and exotic mesorhizobium strains in southern Ethiopia," African Journal of Biotechnology, vol. 15, no. 35, pp. 1920-1929, 2016.

[107] R. Parveen, M. Sadiq, and M. Saleem, "Role of rhizobium inoculation in chickpea (Cicer arietinum L.) under water stress conditions," Pakistan Journal of Biological Sciences, vol. 2, no. 2, pp. 452-454, 1999.
[108] M. N. Esfahani, S. Sulieman, J. Schulze, K. YamaguchiShinozaki, K. Shinozaki, and L.-S. P. Tran, "Mechanisms of physiological adjustment of N2 fixation in Cicer arietinum L. (chickpea) during early stages of water deficit: single or multi-factor controls," The Plant Journal, vol. 79, no. 6, pp. 964-980, 2014.

[109] C. Molina, B. Rotter, R. Horres et al., "SuperSAGE: the drought stress-responsive transcriptome of chickpea roots," BMC Genomics, vol. 9, no. 1, pp. 553-581, 2008.

[110] A. Bano, R. Batool, and F. Dazzo, "Adaptation of chickpea to desiccation stress is enhanced by symbiotic rhizobia," Symbiosis, vol. 50, no. 3, pp. 129-133, 2010.

[111] A. Khadraji, M. Mouradi, and C. Ghoulam, "Growth and mineral nutrition of the chickpea (Cicer arietinum L.)-rhizobia symbiosis under water deficit," Brazilian Archives of Biology and Technology, vol. 60, Article ID e17160325, 2018.

[112] M. Nadeem, J. Li, M. Yahya et al., "Research progress and perspective on drought stress in legumes: a review," International Journal of Molecular Sciences, vol. 20, no. 10, p. 2541, 2019.

[113] J. Slattery, D. J. Pearce, and W. J. Slattery, "Effects of resident rhizobial communities and soil type on the effective nodulation of pulse legumes," Soil Biology and Biochemistry, vol. 36, no. 8, pp. 1339-1346, 2004.

[114] R. Dixon and D. Kahn, "Genetic regulation of biological nitrogen fixation," Nature Reviews Microbiology, vol. 2, no. 8, pp. 621-631, 2004.

[115] I. Aranjuelo, G. Tcherkez, G. Molero, F. Gilard, J. C. Avice, and S. Nogues, "Concerted changes in $\mathrm{N}$ and $\mathrm{C}$ primary metabolism in alfalfa (Medicago sativa) under water restriction," Journal of Experimental Botany, vol. 64, no. 4, pp. 885-897, 2013.

[116] E. Gil-Quintana, E. Larrainzar, A. Seminario et al., "Local inhibition of nitrogen fixation and nodule metabolism in drought-stressed soybean," Journal of Experimental Botany, vol. 64, no. 8, pp. 2171-2182, 2013.

[117] I. Severin, V. Confurius-Guns, and L. J. Stal, "Effect of salinity on nitrogenase activity and composition of the active diazotrophic community in intertidal microbial mats," Archives of Microbiology, vol. 194, no. 6, pp. 483-491, 2012.

[118] P. H. Graham and C. P. Vance, "Legumes: importance and constraints to greater use," Plant Physiology, vol. 131, no. 3, pp. 872-877, 2003.

[119] J. Schulze, G. Temple, S. J. Temple, H. Beschow, and C. P. Vance, "Nitrogen fixation by white lupin under phosphorus deficiency," Annals of Botany, vol. 98, no. 4, pp. 731-740, 2006.

[120] Z. Zhang, H. Liao, and W. J. Lucas, "Molecular mechanisms underlying phosphate sensing, signaling, and adaptation in plants," Journal of Integrative Plant Biology, vol. 56, no. 3, pp. 192-220, 2014.

[121] W. G. Mhango, S. K. Mughogho, W. D. Sakala, and A. R. Saka, "The effect of phosphrous and sulphur fertilizers on grain legumes and maize productivity in northern Malawi," Bunda Journal of Agriculture, Environmental Science and Technolgy, vol. 3, no. 2, pp. 20-27, 2008.

[122] G. Milev, "Effect of foliar fertilization on nodulation and grain yield of pea (Pisum sativum L.)," Turkish Journal of Agricultural and Natural Sciences, vol. 6, pp. 668-672, 2014.

[123] T. R. Sinclair and V. Vadez, "Physiological traits for crop yield improvement in low $\mathrm{N}$ and $\mathrm{P}$ environments," Plant and Soil, vol. 245, no. 1, pp. 1-15, 2002.

[124] S. Sulieman, C. V. Ha, J. Schulze, and L.-S. P. Tran, "Growth and nodulation of symbiotic Medicago truncatula at different 
levels of phosphorus availability," Journal of Experimental Botany, vol. 64, no. 10, pp. 2701-2712, 2013.

[125] S. Kasturikrishna and I. P. S. Ahlawat, "Growth and yield response of pea (Pisum sativum L.) to moisture stress, phosphorus, sulphur and zinc fertilizers," Indian Journal of Agronomy, vol. 44, pp. 588-596, 1999.

[126] R. F. Pegoraro, M. N. D. Almeida Neta, C. A. D. Costa et al., "Chickpea production and soil chemical attributes after phosphorus and molybdenum fertilization," Ciência $e$ Agrotecnologia, vol. 42, no. 5, pp. 474-483, 2018.

[127] S. Das, B. L. Pareek, A. Kumawat, and S. R. Dhikwal, "Effect of phosphorus and biofertilizers on productivity of chickpea (Cicer arietinum L.) in north western Rajasthan, India," Legume Research, vol. 38, pp. 511-514, 2013.

[128] M. Idris, T. Mahmood, and K. A. Malik, "Response of fieldgrown chickpea (Cicer arietinum L.) to phosphorus fertilization for yield and nitrogen fixation," Plant and Soil, vol. 114, no. 1, pp. 135-138, 1989.

[129] S. Kassa, Growth, Yield and Nodulation Response of Chickpea (Cicer arietinum) Varieties to Rhizobia Inoculation and Phosphorus Fertilizer Application at Boditi area, Wolayita, Southern Ethiopia, School of Plant and Horticultural Sciences, Hawassa University, Hawassa, Ethiopia, 2009.

[130] E. Bremmer, C. V. Kessel, and R. Karamanos, "Inoculant, phosphorus and nitrogen responses of lentil," Canadian Journal of Plant Science, vol. 69, pp. 691-701, 1989.

[131] P. W. Singleton, H. M. AbdelMagid, and J. W. Tavares, "Effect of phosphorus on the effectiveness of strains of rhizobium japonicum," Soil Science Society of America Journal, vol. 49, no. 3, pp. 613-616, 1985.

[132] A. K. Das, Q. A. Khaliq, M. M. Haque, and M. S. Islam, "Effect of phosphorus fertilizeron the dry matter accumulation, nodulation and yield in chickpea," Bangladesh Research Publications Journal, vol. 1, pp. 47-60, 2008.

[133] T. Y. Samago, E. W. Anniye, and F. D. Dakora, "Grain yield of common bean (Phaseolus vulgaris L.) varieties is markedly increased by rhizobial inoculation and phosphorus application in Ethiopia," Symbiosis, vol. 75, no. 3, pp. 245-255, 2018.

[134] S. Hussen, F. Yirga, and F. Tibebu, "Effect of phosphorus fertilizer on yield and yield components of chickpea (Cicer arietinum) at Kelemeda, south Wollo, Ethiopia," International Journal of Agricultrural Extension and Rural Development Studies, vol. 1, no. 1, pp. 29-35, 2015.

[135] S. K. Das, B. Biswas, and K. Jana, "Effect of farm yard manure, phosphorus and sulphur on yield parameters, yield, nodulation, nutrient uptake and quality of chickpea (Cicer arietinum L.)," Journal of Applied and Natural Science, vol. 8, no. 2, pp. 545-549, 2016.

[136] S. Lusiba, J. Odhiambo, and J. Ogola, "Growth, yield and water use efficiency of chickpea (Cicer arietinum): response to biochar and phosphorus fertilizer application," Archives of Agronomy and Soil Science, vol. 64, no. 6, pp. 819-833, 2017.

[137] S. Das, R. Nath, and A. Chakraborty, "Performance of chickpea (Cicer arietinum L.) cultivars and estimation of economic optimum doses of phosphorus in an Alfisol of West Bengal," Journal Crop and Weed, vol. 11, pp. 113-117, 2015.

[138] G. Nadia, "Influence of molybdenum on groundnut production under different nitrogen levels," World Journal of Chemistry, vol. 7, no. 2, pp. 64-70, 2012.

[139] J. Jacob and D. W. Lawlor, "Dependence of photosynthesis of sunflower and maize leaves on phosphate supply, ribulose1,5-bisphosphate carboxylase/oxygenase activity, and ribulose-1,5-bisphosphate pool size," Plant Physiology, vol. 98, no. 3, pp. 801-807, 1992.

[140] M. Erman, B. Yildirim, N. Togay, and F. Cig, "Effect of phosphorus application and rhizobium inoculation on yield, nodulation and nutrient up take in field pea (Pisum sativum sp. Arvense. L.)," Journal of Animal and Veterinary Advances, vol. 8, no. 2, pp. 301-304, 2009.

[141] C. Srinivasarao, A. N. Ganeshamurthy, A. Masood, and R. N. Singh, "Effect of phosphorus levels on zinc, iron, copper and manganese removal by chickpea genotypes in typic Ustochrept," Journal of Food Legumes, vol. 20, no. 1, pp. 45-48, 2007.

[142] V. K. Gulpadiya and D. S. Chhonkar, "Effect of phosphorus on growth, productivity and economics of chickpea varieties," Annals of Plant and Soil Research, vol. 16, no. 4, pp. 334-337, 2014.

[143] K. K. Pingoliya, A. K. Mathur, M. L. Dotaniya, D. K. Jajoria, and G. P. Narolia, "Effect of phosphorus and iron levels on growth and yield attributes of chickpea (Cicer arietinum L.) under agroclimatic zone IV A of Rajasthan, India," Legume Research-An International Journal, vol. 37, no. 5, pp. 537-541, 2014.

[144] N. S. Dhillon and A. C. Vig, "Response of lentil to P in relation to organic carbon and olsen, $\mathrm{P}$ in soil," Indian Society of Soil Science, vol. 44, no. 3, pp. 433-436, 1996.

[145] S. Ullah, A. Jan, M. Ali et al., "Response of chickpea (Cicer arietinum L.) to phosphorus and zinc levels and their application methods," Sarhad Journal of Agriculture, vol. 34, no. 3, pp. 575-582, 2018.

[146] E. O. Rodríguez-Navarro and D. Rodríguez-Navarro, "Nitrogen and phosphorus availability limit N2 fixation in bean," New Phytologist, vol. 147, no. 2, pp. 337-346, 2000.

[147] C. Tang, P. Hinsinger, B. T. Jaillard, Z. Rengel, and J.-J. Drevon, "Effect of phosphorus deficiency on the growth, symbiotic N2 fixation and proton release by two bean (Phaseolus vulgaris) genotypes," Agronomie, vol. 21, no. 6-7, pp. 683-689, 2001.

[148] T. Madzivhandila, J. Ogola, and J. Odhiambo, "Growth and yield response of four chickpea cultivars to phosphorus fertilizer rates," Journal of Food, Agriculture and Environment, vol. 10, no. 3-4, pp. 451-455, 2012.

[149] B. K. Garg, "Nutrient uptake and management under drought: nutrient-moisture interaction," Current Agriculture, vol. 27, no. 1-2, pp. 1-8, 2003.

[150] P. Tittonell, S. Zingore, M. T. van Wijk, M. Corbeels, and K. E. Giller, "Nutrient use efficiencies and crop responses to $\mathrm{N}, \mathrm{P}$ and manure applications in Zimbabwean soils: exploring management strategies across soil fertility gradients," Field Crops Research, vol. 100, no. 1-3, pp. 348-368, 2007.

[151] B. T. Bicer, "The effect of phosphorus doses on chickpea cultivars under rainfall conditions," Cercetări Agronomice În Moldova, vol. 47, no. 158, pp. 2014-2019, 2014.

[152] F. Nawaz, N. Khan, J. A. Shah et al., "Yield and yield components of chickpea as affected by various levels of FYM and rhizobium inoculation," Pure and Applied Biology, vol. 6, no. 1, pp. 346-351, 2017.

[153] Y. Goa, D. Bassa, G. Gezahagn, and M. Chichaybelew, "Farmers' participatory evaluation of chickpea varieties in Mirab Badwacho and Damot Fullasa districts of southern Ethiopia," Hydrology Current Research, vol. 8, no. 1, p. 264, 2017.

[154] D. Prasad, A. S. Bangarwa, K. Satish, and R. Asha, "Effect of sowing dates and plant population on chickpea (Cicer 
arietinum) genotypes," Indian Journal of Agronomy, vol. 57, no. 2, pp. 206-208, 2012.

[155] O. Sadeghipour and P. Aghaei, "Comparison of autumn and spring sowing on performance of chickpea (Cicer arietinum L.) varieties," International Journal of Biosciences, vol. 2, no. 6, pp. 49-58, 2012.

[156] S. A. Badini, M. Khan, S. U. Baloch et al., "Effect of phosphorus levels on growth and yield of chickpea (Cicer aretinum L.) varieties," Journal of Natural Sciences Research, vol. 5, no. 3, 2015.

[157] R. Purushothaman, H. D. Upadhyaya, P. M. Gaur, C. L. L. Gowda, and L. Krishnamurthy, "Kabuli and desi chickpeas differ in their requirement for reproductive duration," Field Crops Research, vol. 163, pp. 24-31, 2014.

[158] M. Tesfahun, T. Yemane, and G. Yemane, "Response of two chickpea (Cicer arietinum L.) varieties to rates of blended fertilizer and row spacing at Tselemti district, northern Ethiopia," Advances in Agricuture, vol. 2018, Article ID 5085163, 8 pages, 2018.

[159] L. K. Tripathi, T. Thomas, and S. Kumar, "Impact of nitrogen and phosphorus on growth and yield of chickpea (Cicer arietinum L.)," Asian Journal of Soil Science, vol. 8, no. 2, pp. 260-263, 2013.

[160] A. Mfilinge, K. Mtei, and P. A. Ndakidemi, "Effects of rhizobiunm inoculation and supplementation with $\mathrm{P}$ and $\mathrm{K}$ on growth, leaf chlorophyll content and nitegen fixation of bush bean varieties," American Journal of Research Communication, vol. 2, no. 10, pp. 49-87, 2014.

[161] E. Wolde-meskel, J. van Heerwaarden, B. Abdulkadir et al., "Additive yield response of chickpea (Cicer arietinum L.) to rhizobium inoculation and phosphorus fertilizer across smallholder farms in Ethiopia," Agriculture, Ecosystems \& Environment, vol. 261, pp. 144-152, 2018.

[162] Z. Fatima, M. Zia, and M. F. Chaudhary, "Effect of rhizobium strains and phosphorus on growth of soybean (Glycine max) and survival of rhizobium and P solubilizing bacteria," Pakistan Journal of Botany, vol. 38, no. 2, pp. 459-464, 2006.

[163] M. A. Ali, M. Hussain, W. H. Malik, and M. Tahir, "Evaluation of the effect of rhizobium inoculation and phosphorus, grain yield and nodulation behaviour of Lens culinaris," Pakistan Journal of Life and Social Sciences, vol. 2, no. 2, pp. 112-114, 2004.

[164] A. Namvar and R. S. Sharifi, "Phonological and morphological response of chickpea to symbiotic and mineral nitrogen fertilization," Zemdirbyste-Agriculture, vol. 98, no. 2, pp. 121-130, 2011.

[165] T. Yoseph, Effects of Rhizobium Inoculants and P Fertilization on Growth,yield and Yield Components of Haricot Bean (Phaseolus vulgaris L.) at Umbullo Wacho Watershed, Southern Ethiopia, School of plant and Horticultural Sciences, Hawassa University, Hawassa, Ethiopia, 2011.

[166] M. Ahmed and E. A. Badr, "Effect of bio- and mineral phosphorus fertilizer on the growth, productivity and nutritional value of some chickpea cultivars (Cicer arietinum, L.) in newly cultivated land," Australian Journal of Basic and Applied Sciences, vol. 3, no. 4, pp. 4656-4664, 2009.

[167] D. Dutta and P. Bandyopadhyay, "Performance of chickpea (Cicer arietinum L.) to application of phosphorus and biofertilizer in laterite soil," Archives of Agronomy and Soil Science, vol. 55, no. 2, pp. 147-155, 2009.

[168] A. Zerihun, D. Alemayo, and E. Wolde-Meskel, "On farm yield responses of soybean (Glycine max L. (Merrill)) to fertilizer sources under different soil acidity status in Gobu
Sayo District, western Ethiopia," Journal of Agronomy, vol. 14, no. 1, pp. 30-36, 2015.

[169] P. C. Jain, P. S. Kushwaha, U. S. Dhaked, H. Khan, and S. K. Trivedi, "Response of chickpea (Cicer arietinum L.) to phosphorus and biofertilizer," Legume Research, vol. 22, no. 4, pp. 241-244, 1999.

[170] V. Chekanai, R. Chikowo, and B. Vanlauwe, "Response of common bean (Phaseolus vulgaris L.) to nitrogen, phosphorus and rhizobia inoculation across variable soils in Zimbabwe," Agriculture, Ecosystems \& Environment, vol. 266, pp. 167-173, 2018.

[171] M. Asante, B. D. K. Ahiabor, and W. K. Atakora, "Growth, nodulation, and yield responses of groundnut (Arachis hypogaea L.) as influenced by combined application of rhizobium inoculant and phosphorus in the Guinea savanna zone of Ghana," International Journal of Agronomy, vol. 2020, Article ID 8691757, 7 pages, 2020.

[172] A. S. Abdulameer, "Impact of rhizobial strains mixture, phosphorus and zinc applications in nodulation and yield of bean (Phaseolus vulgaris L.)," Baghdad Science Journal, vol. 8, no. 1, pp. 357-365, 2011.

[173] G. W. Mmbaga, K. M. Mtei, and P. A. Ndakidemi, "Extrapolations on the use of rhizobium inoculants supplemented with phosphorus $(\mathrm{P})$ and potassium $(\mathrm{K})$ on growth and nutrition of legumes," Agricultural Sciences, vol. 5, no. 12, pp. 1207-1226, 2014.

[174] R. Hayat, S. Ali, M. T. Siddique, and T. H. Chatha, "Biological nitrogen fixation of summer legumes and their residual effects on subsequent rainfed wheat yield," Pakistan Journal of Botany, vol. 40, no. 2, pp. 711-722, 2008.

[175] M. Hasan and I. B. Sahid, "Evaluation of rhizobium inoculation in combination with phosphorus and nitrogen fertilization on groundnut growth and yield," Journal of Agronomy, vol. 15, no. 3, pp. 142-146, 2016.

[176] R. S. Patel and Z. G. Patel, "Effect of farmyard manure, nitrogen, phosphorus and Rhizobium inoculation on the growth and yield of gram (Cicer arietinum L.)," Annals of Agricultural Ressearch, vol. 12, pp. 200-202, 1991

[177] B. Ahiabor, S. Lamptey, S. H. Yeboa, and V. Bahari, "Application of phosphorus fertilizer on soybean [(Glycine max L. (Merril)] inoculated with rhizobium and its economic implication to farmers," American Journal of Experimental Agriculture, vol. 4, no. 11, pp. 1420-1434, 2014.

[178] M. A. Tarekegn and K. Kibret, "“Effects of rhizobium, nitrogen and phosphorus fertilizers on growth, nodulation, yield and yield attributes of soybean at Pawe Northwestern Ethiopia," World Scientific News, vol. 67, no. 2, pp. 201-218, 2017. 